\title{
EGFR Signaling in Liver Diseases
}

\author{
Karin Komposch and Maria Sibilia * \\ Received: 21 November 2015; Accepted: 21 December 2015; Published: 29 December 2015 \\ Academic Editor: Johannes Haybaeck \\ Institute of Cancer Research, Department of Medicine I, Comprehensive Cancer Center, \\ Medical University of Vienna, Borschkegasse 8a, A-1090 Vienna, Austria; karin.komposch@meduniwien.ac.at \\ * Correspondence: sibilia-office@meduniwien.ac.at
}

\begin{abstract}
The epidermal growth factor receptor (EGFR) is a transmembrane receptor tyrosine kinase that is activated by several ligands leading to the activation of diverse signaling pathways controlling mainly proliferation, differentiation, and survival. The EGFR signaling axis has been shown to play a key role during liver regeneration following acute and chronic liver damage, as well as in cirrhosis and hepatocellular carcinoma (HCC) highlighting the importance of the EGFR in the development of liver diseases. Despite the frequent overexpression of EGFR in human HCC, clinical studies with EGFR inhibitors have so far shown only modest results. Interestingly, a recent study has shown that in human HCC and in mouse HCC models the EGFR is upregulated in liver macrophages where it plays a tumor-promoting function. Thus, the role of EGFR in liver diseases appears to be more complex than what anticipated. Further studies are needed to improve the molecular understanding of the cell-specific signaling pathways that control disease development and progression to be able to develop better therapies targeting major components of the EGFR signaling network in selected cell types. In this review, we compiled the current knowledge of EGFR signaling in different models of liver damage and diseases, mainly derived from the analysis of HCC cell lines and genetically engineered mouse models (GEMMs).
\end{abstract}

Keywords: EGFR; liver; partial hepatectomy; hepatocellular carcinoma

\section{Epidermal Growth Factor Receptor (EGFR) and Its Ligands}

The epidermal growth factor receptor (EGFR, also known as ErbB1 or HER-1) is a transmembrane receptor that belongs to the family of receptor tyrosine kinases (RTK) [1]. Structurally, the EGFR is composed of an extracellular domain, where EGFR ligands bind to, followed by a transmembrane domain and an intracellular domain, where the tyrosine kinase domain and the carboxy-terminal tail containing key tyrosine residues are located [2,3]. Ligands that can bind EGFR include epidermal growth factor (EGF), transforming growth factor $\alpha$ (TGF- $\alpha$ ), amphiregulin (AR), epiregulin (EREG), betacellulin (BTC), heparin-binding EGF (HB-EGF) and epigen (EPGN) [4]. These ligands contain EGF-like domains that confer binding specificity and additionally contain different motifs, such as sites for heparin binding or glycosylation or an immunoglobulin domain [5]. All ligands are synthesized as transmembrane precursors and are proteolytically cleaved from the surface of the membrane [6] by enzymes that belong to "a disintegrin and metalloproteinases" (ADAM) family, which are also membrane-anchored proteins with metalloprotease activity [7-9]. Among the different ADAM family members involved in EGFR ligand cleavage, ADAM17, also known as tumor necrosis factor $\alpha$ (TNF- $\alpha$ )-converting enzyme (TACE), is supposed to play a key role $[7,8]$.

Upon ligand binding, EGFR can form homo- or heterodimers with other EGFR family members. Following activation of the intrinsic kinase domain, several proteins containing Src-homology 2 domains (SH2) such as growth factor receptor-bound protein 2 (Grb2), SHC-transforming protein (SHC), and phospholipase $\mathrm{C} \gamma(\mathrm{PLC} \gamma)$ can bind to the phosphorylated tyrosine residues within 
the EGFR and activate complex downstream signaling cascades $[1,10,11]$. The main activated downstream signaling pathways are the Ras-Raf-MEK-ERK1/2 and the signal-transducer and activator of transcription (STAT) 3 and 5 pathways controlling proliferation and differentiation and the phosphatidylinositol-3-kinase (PI3K)-Akt-mechanistic target of rapamycin (mTOR) pathway controlling survival [1,10,11].

The EGFR can form complexes also with other RTKs to initiate signaling, such as platelet-derived growth factor receptor (PDGFR) [12,13], insulin-like growth factor 1 receptor (IGF1-R) [14] or hepatocyte growth factor receptor (c-Met) [15]. This can occur via ligand-dependent or ligand-independent mechanisms, in the latter case physical interaction of receptors with EGFR is believed to be required [12,14]. Moreover, EGFR signaling can be transactivated by several other receptor families, like by cytokine receptors such as interferon- $\gamma$-bound receptors and growth hormone-bound receptors [16,17] as well as integrins via Src kinases [18]. G-protein-coupled receptors (GPCRs) have been shown to transactivate EGFR via ADAM protease activation and cleavage of EGFR ligands [7,8,19-21]. Furthermore, ligands for GPCRs [20,21], growth hormone (via Src activation) and prolactin (via Janus kinase 1 (Jak1) activation) can phosphorylate EGFR in a ligand-independent manner [22]. In addition, bile acids have been shown to transactivate EGFR [23].

\section{EGFR and Its Ligands during Liver Development}

Several groups generated knockout mice deficient of EGFR and its ligands [24]. AR, BTC, EGF, EREG and EPGN knockout mice did not show any overt phenotype or histological abnormalities [25-28], beside a mild mammary gland phenotype observed in virgin AR knockout mice [25]. Conversely, more than half of the HB-EGF-deficient mice died before weaning, with survivors showing severe heart abnormalities $[27,29]$. TGF- $\alpha$-deficient mice displayed abnormal skin architecture, curly hair and whiskers and an open eye phenotype at birth, whereas several other tissues did not show altered appearance of structure and function [30,31]. AR, EGF and TGF- $\alpha$ triple knockout mice developed similar but more severe abnormalities than TGF- $\alpha$-deficient mice regarding eye and skin abnormalities. However, triple knockout mice survived for one year showing no additional overt abnormalities [25]. HB-EGF and BTC double knockout mice displayed a more severe heart phenotype compared to HB-EGF single knockout mice [27].

Loss-of-function studies of EGFR point to an indispensable role for EGFR during embryonic development, as EGFR knockout neonates showed severe growth retardation. Depending on the genetic background, EGFR-deficient mice died between mid-gestation and postnatal day 20 after birth [32-34]. Concerning liver development, we reported that histological examination of the liver at embryonic day 18.5 and in newborn mutant fetuses revealed no obvious abnormalities [33], whereas Threadgill et al., observed that by postnatal day 8 livers had thickened hepatocyte cords, distorted sinusoidal anatomy, and abnormally vacuolizatized nuclei [34]. Further studies from our laboratory using conditional knockout mice revealed that perinatal deletion of EGFR in hepatocytes alone with the transgenic Alfp-Cre line resulted in reduced body size and weight, which became apparent from the third postnatal week onwards [35]. However, besides growth retardation and body size reduction, mice did not show any liver abnormalities. EGFR deletion in the liver around postnatal day 9 by employing the polyinosinic:polycytidylic acid (polyI:C)-inducible Mx-Cre transgenic line did not lead to growth retardation. However, absence of the EGFR protein in the liver of these mice occurred only 3-4 weeks after induction of recombination, providing a possible explanation for the different phenotype compared to Alfp-Cre-mediated deletion [35]. These results suggest that EGFR and its ligands are not crucial for embryonic liver development.

\section{EGFR and Its Ligands in Liver Regeneration}

Upon tissue damage, the liver can activate an incommensurable repair machinery aimed at protection of liver tissue and restoration of the damaged tissue mass [36]. Profound evidence has accumulated over the years corroborating an indispensable role for EGFR in liver repair and 
regeneration. Among all tissues, the EGFR is highest expressed in hepatocytes of the adult liver [37], indicating an important role in maintaining liver function. EGF has been shown to be mitogenic in unchallenged livers of rats when infused exogenously [38]. Treatment of cirrhotic rats with EGF and insulin after partial hepatectomy accelerated liver DNA synthesis [39]. EGFR ligands like TGF- $\alpha$, AR, HB-EGF and EREG induced strong mitogenic signals in cultured hepatocytes [26,40-48]. Protein levels of TGF- $\alpha$, AR, HB-EGF and EREG increased rapidly after partial hepatectomy $[26,43,49,50]$ as well as ADAM17 expression [51]. Furthermore, AR and HB-EGF substantially contributed to liver regeneration after partial hepatectomy as knockout of AR and HB-EGF led to desynchronized $S$ phase entry of hepatocytes [43,52], whereas loss of EREG or TGF- $\alpha$ had no effect $[26,53]$. However, TGF- $\alpha$ improved hepatic DNA synthesis after hepatectomy in rats with carbon tetrachloride $\left(\mathrm{CCl}_{4}\right)$-induced cirrhosis [54]. These results suggest that EGFR ligands play different roles during liver regeneration. Furthermore, loss of some EGFR ligands impairs liver regeneration more severely than loss of others, which is probably attributable to redundant expression.

Following partial liver transplantation, whereby the livers of mice were reduced to $50 \%$ and transplanted, an increase in AR expression was observed, which resulted in EGFR phosphorylation and induction of proliferation. Injection of AR was able to stimulate liver regeneration even in $30 \%$ grafts. Administration of an AR neutralizing antibody attenuated liver regeneration and inhibition of EGFR suppressed liver regeneration in 50\% grafts [55]. However, cell transplantation of TGF- $\alpha$ overexpressing hepatocytes could preserve hepatocyte function, as these hepatocytes showed higher proliferation rates [56]. In line with this, overexpression of HB-EGF in transgenic mice led to an increase in proliferating hepatocyte numbers [57]. Interestingly, ablation of salivary glands, which are the main source of EGF in rodents, blocked hepatocytes in the G1 phase. This can be overcome by the administration of EGF [58-60]. These results highlight the potential therapeutic use of EGFR ligands to induce liver regeneration.

EGFR binding and EGFR mRNA levels in the liver peak by about threefold 8 hours after partial hepatectomy [61]. The role of EGFR in liver regeneration has been studied in liver- or hepatocyte-specific knockout mouse models [35,62], in transgenic mice expressing dominant negative mutants of EGFR [63], in rats by RNAi injection [64] and in mice using EGFR inhibitors [65]. Inhibition of EGFR with anti-EGFR monoclonal antibodies after partial hepatectomy showed no effect on liver regeneration and cellular proliferation [65]. In EGFR-deficient livers, regeneration was impaired after 2/3 hepatectomy showing reduced cyclin D1 expression and impaired G1-S phase entry, demonstrating that EGFR is a critical regulator of hepatocyte proliferation in the initial phases of liver regeneration [35] (Figure 1a). In contrast to this, it was shown that liver regeneration after 70\% hepatectomy in mice that lack EGFR specifically in hepatocytes revealed only a mild phenotype with no change in cyclin D1 expression and only slight differences in cyclin A expression compared to control livers [62]. However, a delay in proliferation could be observed in both studies, but was more pronounced in the first study [35]. In line with this, a recently published study employing a novel transgenic mouse model expressing a dominant negative mutant of EGFR revealed a critical role for the catalytic activity of EGFR during early stages of liver regeneration following partial hepatectomy [63]. Although no mortality and delay of liver regeneration was observed in EGFR-silenced rats after partial hepatectomy, shEGFR treatment suppressed mitosis and proliferation. However, limitations of this system comprise the fact that EGFR messenger RNA (mRNA) and protein were not completely absent [64]. These results consistently demonstrate that EGFR is a critical regulator of hepatocyte proliferation in the initial phases of liver regeneration (Figure 1a).

EGFR can also be indirectly activated during liver regeneration. For example, growth hormone (GH) signaling was shown to control EGFR mRNA expression in the liver from G0 to mid G1 phase transition [66]. Furthermore, GH-receptor-deficient mice showed impaired liver regeneration after partial hepatectomy, which was suggested to be due to impaired EGFR activation [66]. After partial hepatectomy, downregulation of GH and EGFR was observed in two different mouse models of steatosis, a genetic (ob/ob mice) and a methionine- and choline-deficient (MCD) diet model, which 
could be partially rescued by the administration of GH, which in turn was associated with the restoration of EGFR expression in the liver [67]. Reduced EGFR expression was also responsible for impaired liver regeneration when $\beta$-catenin was specifically deleted from hepatocytes [68]. After partial hepatectomy, matrix metallopeptidase 9 (MMP-9) deficiency was reported to impair liver regeneration through inhibition and delay of EGFR activation. Additionally, in MMP-9 knockout mice, the EGFR ligands HB-EGF and AR were expressed at lower levels [69]. Different mechanisms that indirectly lead to EGFR downregulation add to the complexity of this important growth factor signaling pathway, but open the way for new therapeutic treatment options via indirect EGFR modulation.

$\mathbf{a}$

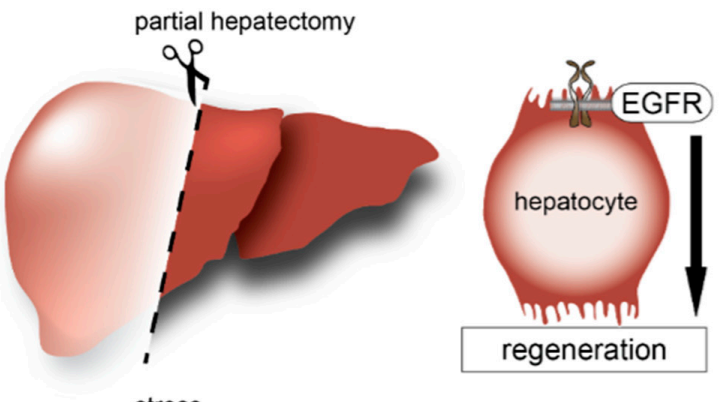

b

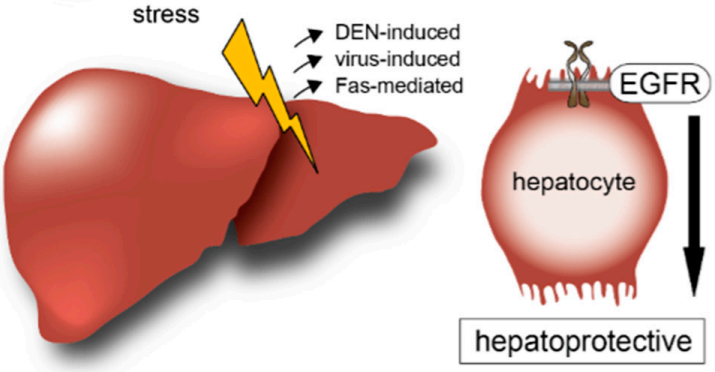

c
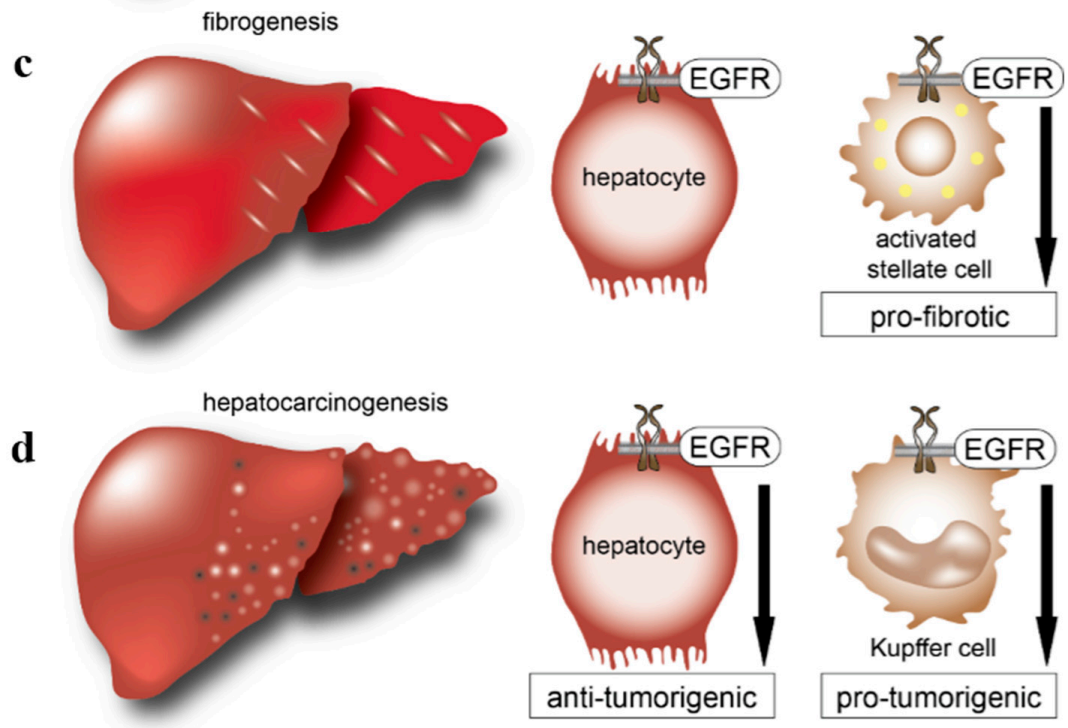

Figure 1. Overview of cell-type-specific roles of epidermal growth factor receptor (EGFR) during liver injury and disease. (a) After partial hepatectomy, EGFR is crucial in hepatocytes for liver regeneration; (b) During stress, liver injury models induced by diethylnitrosamine (DEN), viruses or Fas, the EGFR plays a hepatoprotective role, but the underlying signaling mechanisms remain unclear; (c) After toxic liver injury, the EGFR is dispensable in hepatocytes but essential on activated hepatic stellate cells to induce fibrosis; (d) During hepatocarcinogenesis, EGFR is suggested to play an anti-tumorigenic role in hepatocytes, whereas EGFR in Kupffer cells/liver macrophages plays a pro-tumorigenic role. 


\section{EGFR and Its Ligands in Experimental Models of Acute Liver Damage}

In a model of Fas-mediated liver injury, AR, EREG and TGF- $\alpha$ were found to be upregulated [70], whereas further administration of AR to mice abrogated Fas-mediated liver injury and showed direct anti-apoptotic effects in primary hepatocytes [70]. AR is undetectable in the healthy liver [43], but is induced by inflammatory signals, where AR was shown to attenuate hepatic acute-phase gene expression [71]. Overexpression of TGF- $\alpha$ has shown a strong protective effect on Fas-mediated hepatic apoptosis [56,72]. In line with this, hepatic HB-EGF gene transduction in vivo could show therapeutic effects for Fas-induced liver injury [73]. Moreover, loss of ADAM17 in hepatocytes promoted Fas-induced apoptosis, which led to the conclusion that ADAM17 is protective against Fas-mediated liver injury in part also because of increased shedding of EGFR ligands, which can be hepatoprotective. EGFR signaling further protected against Fas-mediated hepatotoxicity [74], whereas cyclooxygenase-2 (COX-2) could prevent Fas-induced hepatocyte apoptosis and liver failure partially through EGFR upregulation [75]. These results demonstrate that the EGFR signaling system is hepatoprotective against Fas-mediated liver injury (Figure 1b).

The EGFR was also shown to be hepatoprotective following treatment with diethylnitrosamine (DEN), a chemical carcinogen commonly used to induce HCC formation in rodents. We reported that mice lacking EGFR in hepatocytes showed increased levels of serum aspartate transaminase (AST) and serum alanine transaminase (ALT), markers for acute liver toxicity [76]. In line with this, damaged areas were significantly increased in livers lacking EGFR in hepatocytes with higher levels of cleaved caspase 3. Stimulation of isolated hepatocytes with DEN resulted in a strong necrotic response [76], which points to a cell-autonomous effect. Furthermore, EGFR-deficient hepatocytes were more sensitive to tumor necrosis factor $\alpha$ (TNF- $\alpha$ ) and cycloheximide (CHX) treatment. These results show that EGFR signaling protects from apoptosis and necrosis during DEN-induced liver damage, highlighting the important hepatoprotective role of EGFR [76] (Figure 1b).

\section{EGFR and Its Ligands in Experimental Models of Chronic Liver Damage}

Non-alcoholic steatohepatitis (NASH) can occur due to fat deposition in the liver and is together with alcoholic liver disease (ALD) the most common cause of chronic liver diseases in Western countries [77,78]. Liver fibrosis occurs in most types of chronic liver diseases and is characterized by excessive deposition of extracellular matrix (ECM) proteins [79]. Architectural changes of the liver finally lead to cirrhosis, the formation of pre-neoplastic nodules and the development of hepatocellular carcinoma [80]. Therefore, liver injury and concomitant cirrhosis are strongly linked to hepatocarcinogenesis. As the roles of EGFR ligands and its receptor EGFR in fibrosis and cirrhosis are not completely understood, they have been studied in experimental models of chronic liver injury as well as in the liver of cirrhotic patients.

Upon chronic toxic injury of mouse livers via $\mathrm{CCl}_{4}$ or thioacetamide intoxication, the hepatic expression of HB-EGF, TGF- $\alpha$ and AR was increased [49,70,81-83], although AR was undetectable in healthy murine livers [43]. In line with this, AR-deficient mice developed less fibrosis. In $\mathrm{CCl}_{4}$-induced liver fibrosis, AR contributed to the expression of fibrotic markers and stimulated cell proliferation and survival of fibrogenic cells [84]. AR activated human hepatic stellate cells (HSC) and induced proliferation. Conversely, conditional deletion of HB-EGF in the liver accelerated $\mathrm{CCl}_{4}$-induced liver fibrosis [85]. HB-EGF was also expressed in primary cultures of murine HSCs, where HB-EGF inhibited HSC activation [86]. Therefore, HB-EGF is suggested to have a suppressive function in experimental liver fibrosis in mice, in contrast to AR. Conversely, it was shown that HB-EGF promotes HSC proliferation via activation of the EGFR and that HB-EGF is a potential therapeutic target in liver fibrosis [87]. In vitro, EGF promoted DNA synthesis in $\mathrm{CCl}_{4}$-induced primary rat hepatocytes [88], whereas in vivo, administration of EGF before $\mathrm{CCl}_{4}$ intoxication protected from injury, as it resulted only in minimal changes and a minor rise in serum transaminase levels [89]. Moreover, EGF and fibroblast growth factor 2 (FGF-2) synergistically downregulated the expression of fibrotic markers in human primary activated HSC [90]. Whereas studies indicate that EGF is anti-fibrogenic in toxic 
fibrosis, AR is suggested to have a pro-fibrogenic role, which highlights how diverse different EGFR ligands exert their functions by probably activating different EGFR downstream signaling pathways.

In vivo, the role of EGFR during chronic liver disease was examined by investigating the effect of the EGFR inhibitor erlotinib on toxic $\left(\mathrm{CCl}_{4}\right.$-induced) fibrosis in mice and on biliary fibrosis (induced via bile duct ligation) and cirrhosis (DEN-induced) in rats [91]. Erlotinib decreased hepatocyte proliferation and liver injury, and prevented the progression of cirrhosis and regressed fibrosis in some animals [91]. Surprisingly, loss of hepatocyte EGFR alone had no effect on the regenerative response after $\mathrm{CCl}_{4}$-induced liver injury (Figure 1c) [62]. Interestingly, additional loss of c-Met in hepatocytes resulted in enhanced necrosis and delayed liver regeneration compared to loss of hepatic c-Met alone, suggesting that EGFR and c-Met may partially compensate for the loss of each other [62].

However, EGFR is also expressed on HSCs (Figure 1c) [91,92], which is thought to be the major cell type involved in liver fibrosis. Conditional deletion of EGFR in all liver cells including HSCs or in HSCs alone had no effect on the progression of $\mathrm{CCl}_{4}$-induced fibrosis and recovery (Komposch et al., unpublished data). However, other studies have shown that the EGFR inhibitor erlotinib prevented disease progression by reducing EGFR phosphorylation in HSCs and by lowering the total number of activated HSCs [91]. In a recent study, activated HSCs were treated with an anti-EGFR single chain fragment variable antibody-TRAIL (tumor necrosis factor-related apoptosis-inducing ligand) (scFv425-sTRAIL) fusion protein, which significantly reduced viability and ECM production in activated HSCs, but did not exert its effect on parenchymal cells. Blockade of activated HSCs with a monoclonal anti-EGFR antibody reduced the effect of the scFv425-sTRAIL fusion protein [93]. Another study reported that bone morphogenetic protein 7 (BMP-7) was capable of inhibiting liver fibrosis by suppressing HSCs activation by a mechanism involving EGFR and TGF- $\beta 1$ inhibition [94]. Interestingly, bile acids were shown to induce HSC proliferation via activation of EGFR in vitro [95]. Mechanistically, in quiescent primary rat HSCs hydrophobic bile acids induce nicotinamide adenine dinucleotide phosphate (NADPH) oxidase-driven reactive oxygen species (ROS) generation and subsequent Yes-mediated EGFR activation, which shifts from a proliferative to an apoptotic signal when c-Jun N-terminal kinase (JNK) is activated at the same time [96]. Furthermore, EGFR transactivation occurred in HSCs and was induced by angiotensin II via activation of ADAM17 [97]. Taken together, these results suggest that eliminating activated HSCs from the liver during fibrosis might be a new therapeutic approach, which needs further proof in animal studies.

The roles of the EGFR ligands HB-EGF and EREG have also been studied in models of biliary fibrosis that include bile duct ligation (BDL) and 3,5-diethoxycarbonyl-1,4-dihydrocollidine (DDC) feeding in mice. Conditional deletion of HB-EGF in the liver enhanced liver fibrosis after BDL in mice [98]. In DDC fed mice, EREG was upregulated, which correlated with data obtained from serum from patients with liver injury. In mice overexpressing EREG, proliferation of hepatocytes was significantly increased and the number of liver progenitor cells increased, suggesting that EREG would be a useful biomarker for liver regeneration [99].

In a mouse model of NASH induced by a MCD diet as well as in patient samples of NASH, AR was found upregulated [100]. Conversely, TGF- $\alpha$ overexpression attenuated NASH after MCD feeding of mice partially because of upregulation of matrix metalloproteinase-1 (MMP-1), which could be blocked by gefitinib in a human HSC line in vitro [101]. During alcohol-induced liver damage, TGF- $\alpha$ expression increased, which stimulated collagen synthesis when administered on rat HSCs [102]. Interestingly, administration of EGF protected the liver against alcohol-induced liver damage [103]. These results show that the EGFR system plays an important role during acute and chronic liver diseases, which are the pre-stages on the way to hepatocellular carcinoma development.

\section{EGFR and Hepatocellular Carcinoma}

Hepatocellular carcinoma (HCC) is the second leading cause of cancer related death worldwide, whereas in more developed countries it is the sixth leading cause of cancer death. HCC is less common in women than in men [104]. During 2012, approximately 782,500 new cases of liver cancer and 745,500 
deaths from liver cancer occurred worldwide. About $50 \%$ of new cases and deaths account for China, which is leading the statistics due to a high prevalence of chronic hepatitis B virus infection [104]. Besides hepatitis $B$ virus (HBV) and hepatitis $\mathrm{C}$ virus (HCV) infection, other risk factors for liver cancer in Western countries include obesity, type II diabetes, cirrhosis related to heavy alcohol consumption and non-alcoholic liver disease including NASH [105-108].

EGFR is overexpressed in human cirrhotic liver tissue and HCCs $[109,110]$. Overexpression of EGFR occurs in $68 \%$ of human HCC correlating with aggressive tumors, metastasis, and poor patient survival [111-113]. Overexpression of the EGFR ligands TGF- $\alpha$, EGF, HB-EGF, AR, and BTC as well as ADAM17 has also been observed in human liver tumor cells and tissues [109,110,114-117]. Although overexpression of EGFR is present in the majority of HCCs, this increased EGFR expression does not correlate with an increase in EGFR gene copy number [118]. Interestingly, a functional polymorphism in the EGF gene was associated with increased risk for HCC in patients with liver cirrhosis $[119,120]$. Intriguingly, as HCC occurs more frequently in man than in women, EGFR overexpression frequency in males could be correlated to a subclass of HCCs with polysomy of chromosome 7 [121].

Higher microvessel density was observed in HCC patient samples with EGFR-positive tumor endothelial cells. EGFR expression in tumor endothelial cells correlated with BTC expression in tumor cells, suggesting paracrine signaling [115]. Another study could show that in HCCs and chronic liver diseases the EGFR was mainly located in the sinusoidal endothelial cells [122]. However, there are no reports that describe EGFR expression in endothelial cells in the healthy liver.

\section{EGFR and Its Ligands in Hepatitis B Virus-Induced Hepatocellular Carcinoma}

There have been many different attempts to model human liver cancer in mice by expressing HBV components. The HBV $x$ gene and protein are suggested to be involved in the pathogenesis of HBV-induced hepatocellular carcinoma formation, but the underlying mechanisms are unclear. While the HBV $x$ gene is often integrated into cellular DNA during hepatocarcinogenesis, the HBV $x$ protein promotes cell cycle progression, inactivates negative growth regulators and inhibits tumor suppressor genes [123]. In human hepatoma-derived cells, transfection experiments using expression vectors of HBV $x$ demonstrated that the $x$-gene product is capable of inducing EGFR overexpression [124]. Furthermore, it was shown that the enhancer-x region contributes to the malignant change of liver cells in HBV carriers through activation of specific genes, such as EGFR [125]. Furthermore, transgenic mice expressing the HBV x protein were shown to be more likely to develop carcinogen-induced HCC [126]. In a more recent study, the HBV-encoded $x$ protein indirectly downregulated EGFR expression in HCC cells via microRNA-7, resulting in decreased growth rate of these cells. Restoration of EGFR expression was able to restore the growth rate [127].

Interestingly, in patient tissue with chronic hepatitis B, TGF- $\alpha$ levels were elevated and even higher than in patient tissue with chronic hepatitis C [114]. During disease, TGF- $\alpha$ overexpression seems to be associated with hepatocyte regeneration of hepatitis B surface antigen (HBsAg)-injured hepatocytes. Continued TGF- $\alpha$ expression might induce dysplasia and finally hepatocarcinogenesis [128]. In a novel HBV mouse model, EGFR was found upregulated on intrahepatic regulatory $\mathrm{T}$ (Treg) cells, which rendered them more immunosuppressive and more potent in restraining CD8+ T cell-mediated anti-viral activity, resulting in a higher HBV load in hepatocytes [129]. Furthermore, AR was significantly upregulated in HBV-infected livers. In vitro, AR promoted the immunosuppressive activity of EGFR-positive Tregs by inhibiting the production of anti-viral components in CD8+ $\mathrm{T}$ cells [129]. Thus, the EGFR system is suggested to contribute to immune tolerance and viral amplification after HBV infection.

\section{EGFR in Hepatitis C Virus-Induced Hepatocellular Carcinoma}

Beside HBV infection, the main risk factors for HCC include HCV infection. Every year, 3-4 million new HCV infections occur, whereas $60 \%-70 \%$ of them develop chronic liver diseases, $5 \%-20 \%$ develop cirrhosis due to chronic infection and $1 \%-5 \%$ will die from complications such as HCC. 
EGFR is frequently overexpressed in the liver of about $50 \%$ of chronic hepatitis $\mathrm{C}(\mathrm{CHC})$ patients and often together with TGF- $\alpha$ in cirrhotic CHC compared to non-cirrhotic cases [130]. However, the levels of TGF- $\alpha$ and EGF in chronic viral hepatitis were lower compared to HCC $[114,131]$. Furthermore, EGFR plasma concentrations were significantly higher in HCC patients in the presence of HCV and HBV infection, suggesting that plasma EGFR could serve as a marker for HCC, in particular when carcinogenesis is affected by virus infection [132]. HCV infection can lead to an increase in AR expression in hepatocytes, and it is believed that AR is responsible for efficient HCV assembly and virion release. Furthermore, AR protected infected cells from HCV-induced cell death and facilitated liver cirrhosis and HCC progression [133].

Studies on transgenic mice showed that the HCV core protein plays a key role in hepatocarcinogenesis [134]. In vitro, it promoted proliferation of human hepatoma cells by activation of the MAPK/ERK pathway through upregulation of TGF- $\alpha$ transcription via nuclear factor "kappa-light-chain-enhancer" of activated B-cells (NF-kB) [135]. Interestingly, binding of HCV particles to human hepatocytes induced EGFR activation. HCV entry is suggested to be dependent on co-receptor complex formation between CD81 and claudin-1 on the host cell membrane. In vitro, EGFR ligands that enhanced the rate of HCV entry were shown to induce EGFR internalization and co-localization with CD81 but not claudin-1. EGFR kinase inhibitors were shown to be successful inhibitors of HCV infection by preventing endocytosis of EGFR, whereas inhibition of EGFR ligand binding or of EGFR downstream signaling pathways did not affect HCV entry [136,137]. Mechanistically, EGFR was shown to regulate HCV entry by the activation of the EGFR/Shc/Grb2/ Harvey rat sarcoma viral oncogene homolog (HRas) signaling pathway [138]. Furthermore, downstream of EGFR, Ras/MEK/ERK led to the activation of MAPK interacting serine/threonine kinase 1 (MKNK1), which was identified as a host factor in HCV entry [139]. Interestingly, the HCV non-structural protein NS5A attenuated EGFR signaling by alteration of the trafficking profile of EGFR [140] and was able to block EGFR degradation [141]. Noteworthy, also bile acids were demonstrated to play a role in EGFR activation during viral infection. Bile acids promoted HCV replication through activation of EGFR and ERK signaling in infected cells, whereas inhibition of EGFR and ERK could attenuate viral replication [142]. Moreover, IFN- $\alpha$ inducible protein 6 (IFI6) was shown to inhibit HCV entry by impairing EGFR-mediated CD81-claudin-1 interactions [143]. In infected cells, erlotinib synergized with IFN- $\alpha$ to impair HCV replication [144]. These studies highlight the important role of EGFR during HCV entry into the target cell and suggest EGFR inhibitors to successfully constrain viral entry and viral replication.

\section{EGFR and Its Ligands in Genetically Engineered Mouse Models (GEMMs) of Hepatocellular Carcinoma}

So far, it has not been possible to model EGFR-induced liver cancer in mice, as all the attempts to generate GEMMs that overexpress EGFR have been unsuccessful [24], whereas transgenic overexpression has been successful for the EGFR ligands EGF [145,146], TGF- $\alpha[147,148]$, AR [149], BTC [150], HB-EGF [151] and EPGN [152]. Livers of transgenic mice that constitutively overexpress human TGF- $\alpha$ from the mouse metallothionein 1 promoter frequently developed multifocal, well-differentiated HCCs $[147,148,153]$ and treatment of these mice with hepatic carcinogens further accelerated HCC development [153]. Treatment of TGF- $\alpha$-deficient mice with hepatocarcinogens resulted in the development of multiple, but small pre-neoplastic foci indicating that TGF- $\alpha$ plays an important role in the progression of HCC from small foci to large tumors [53]. In addition, ethanol intake promoted hepatocellular lesions that expressed TGF- $\alpha$ [154]. Interestingly, TGF- $\alpha$ and c-myc double transgenic mice have shown accelerated development of hepatic neoplasia when compared to the expression of one of these transgenes. Treatment of TGF- $\alpha$ and c-myc double transgenic mice with DEN and Phenobarbital further accelerated the development of neoplasia in the liver $[155,156]$. EGF upregulation is observed in cirrhotic liver disease [157] and has been shown to promote hepatocellular carcinogenesis [158], whereas EGF expression in cirrhotic but non-tumoral tissue correlated with 
reduced post-surgical survival time [159]. Inflammation led to HB-EGF induction in mesenchymal cells, which stimulated DNA replication in premalignant hepatocytes contributing to HCC development in the early stages [160]. Furthermore, silencing of AR in HCC cells led to reduction of EGFR signaling, inhibition of cell proliferation and increased apoptosis [117]. Interestingly, a new regulatory mechanism for EGFR signaling linking inflammatory and tumor-promoting signals in HCC was proposed, as TNF- $\alpha$ was shown to induce AR shedding and therefore EGFR transactivation in HCC cells [161]. In human HCC cells, fibroblast growth factor 19 (FGF-19) induced AR gene expression via activation of $\beta$-catenin. These results introduce a novel crosstalk between the EGFR and FGF system, which was also identified as a driver in hepatocarcinogenesis [162].

EGFR ligands are also able to stimulate the expression of connective tissue growth factor (CTGF) [163]. Overexpression of CTGF correlated with poor prognosis suggesting that downregulation of CTGF by inhibition of transforming growth factor $\beta$ (TGF- $\beta$ ) may offer clinical benefits [164]. Of note, inhibition of reactive oxygen species (ROS) production attenuated growth of liver tumor cells, which coincided with decreased EGFR phosphorylation and downregulation of EGFR and TGF- $\alpha$ [165]. Adding to complexity, TGF- $\alpha$, HB-EGF, and AR were shown to be released following EGFR transactivation by GPCRs in a variety of cancer cell lines [19,166,167]. Interestingly, mitogen-inducible gene-6 (Mig-6), a multi-adaptor protein and mucin-15 (MUC15), which are expressed in epithelial cells, have been identified as negative regulators of EGFR signaling. Downregulation of Mig-6 and MUC15 frequently occurs in human HCC and correlates with EGFR overexpression $[168,169]$.

In a recent study in GEMMs, we identified a pro-tumorigenic role for EGFR in Kupffer cells and/or liver macrophages [76] (Figure 1d). We were able to show that deletion of EGFR in hepatocytes led to increased hepatocarcinogenesis, whereas deletion of EGFR in Kupffer cells/liver macrophages severely reduced the development of HCC in mice (Figure 1d) [76]. Mechanistically, we could demonstrate that damaged EGFR-deficient hepatocytes undergo more necrosis and apoptosis and produce increased levels of IL-1 $\beta$ leading to enhanced stimulation of Kupffer cells, which subsequently produce high levels of IL-6, thus triggering massive compensatory hepatocyte proliferation ultimately leading to increased HCC formation (Figure 2) [76]. These results suggest that EGFR is protective in hepatocytes by suppressing apoptosis and necrosis.

Furthermore, EGFR signaling in hepatocytes prevents excessive IL-1 $\beta$ production and consequent Kupffer cell activation and compensatory proliferation, suggesting an anti-tumorigenic role for EGFR in hepatocytes in this murine model of chemical carcinogenesis [76]. Surprisingly, EGFR-deficient Kupffer cells failed to produce IL-6 in response to IL-1 $\beta$, therefore leading to reduced HCC formation [76]. In line with this, previous studies have shown that IL-6 is the major driver for hepatocarcinogenesis as IL-6 deletion reduced HCC development [170]. We could furthermore demonstrate that IL-6 production in Kupffer cells following IL-1 $\beta$ stimulation occured in a bimodal way. First IL-1 $\beta$ stimulation of Kupffer cells led to MyD88- and inhibitor of $\mathrm{\kappa B}(\mathrm{I} \mathrm{KB})$ kinase (IKK)-dependent induction of the EGFR ligands HB-EGF, TGF- $\alpha$, AR and EREG as well as ADAM17, which is the protease needed for their cleavage. Subsequently, activation of EGFR leads to IL-6 production via JNK, p38 and IKK [76]. Interestingly, the transcriptional regulation of EGFR ligands and ADAM17 following IL-1 $\beta$ stimulation was independent of EGFR signaling [76]. Moreover, EGFR ligands were not induced in Kupffer cells lacking MyD88 indicating that their induction is under direct control of the IL1-receptor signaling pathway [76]. In line with this, after IL-1 $\beta$ stimulation of Kupffer cells in vitro, AR was significantly induced in EGFR-proficient and EGFR-deficient Kupffer cells. AR induction was prevented by inhibition of ADAM17 and IKK, but not by inhibition of JNK or p38, indicating that AR release is dependent on IKK-mediated ADAM17 activation (Figure 2) [76]. Furthermore, EGF stimulation of MyD88 knockout Kupffer cells restored IL-6 induction demonstrating that IL-6 production is under direct control of EGFR signaling. Taken together, our data suggest that IL-1 $\beta$ stimulation of Kupffer cells leads to EGFR ligand shedding and subsequent EGFR transactivation, which is required to induce IL-6 release from Kupffer cells [76]. In view of this pivotal role of EGFR in Kupffer cells/liver macrophages during 
inflammation-driven HCC formation, EGFR-positive Kupffer cells might be a useful prognostic marker and could represent a new therapeutic target for HCC.

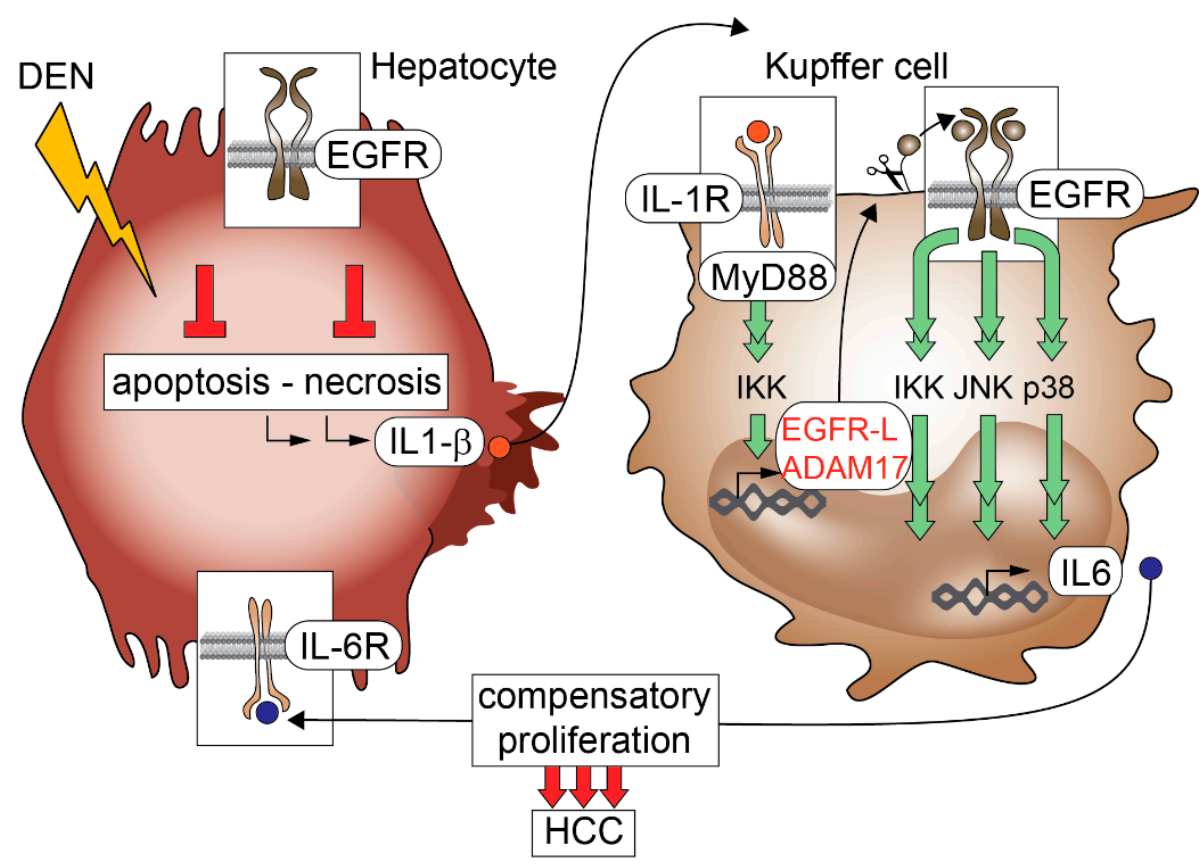

Figure 2. EGFR function in hepatocytes and Kupffer cells during hepatocellular carcinoma (HCC) formation. EGFR signaling is hepatoprotective during diethylnitrosamine (DEN)-induced liver damage. In the absence of EGFR, hepatocytes undergo more necrosis and apoptosis leading to increased IL-1 $\beta$ production, which stimulates Kupffer cells to release IL-6, which is required for compensatory proliferation and repair of damaged hepatocytes. IL-1 $\beta$-induced IL-6 production in Kupffer cells is dependent on EGFR expression and occurs in a bimodal way involving the activation of the IL-1R/MyD88 pathway to first induce EGFR ligands and ADAM17 expression with subsequent EGFR transactivation required for IL-6 production via c-Jun N-terminal kinase JNK, p38 and inhibitor of $\kappa \mathrm{B}(\mathrm{I} \kappa \mathrm{B})$ kinase IKK. Red circles: IL-1 $\beta$, Grey circles: EGFR-ligand, Blue circles: IL-6. Arrows indicate receptor activation.

\section{EGFR Inhibitors in Experimental Hepatocellular Carcinoma (HCC)}

Inhibiting EGFR either with small molecule inhibitors such as the EGFR tyrosine kinase inhibitors gefitinib or erlotinib or with anti-EGFR antibodies such as cetuximab has given promising results in HCC cell lines and in animal studies. Cetuximab was effective in inhibiting cell cycle and inducing apoptosis in HCC cell lines [171]. In human HCC cells, gefitinib and erlotinib induced growth inhibition, apoptosis and cell cycle arrest [171-173]. Erlotinib exerted its effect via MAPK and STAT inhibition, which led to an overexpression of pro-apoptotic and downregulation of anti-apoptotic factors, as well as to a regulation of cell cycle genes towards a G1/G0-arrest [174]. Inhibition of EGFR with gefitinib in rats that developed DEN-induced HCCs following cirrhosis significantly reduced the number of HCC nodules compared to untreated rats [175]. In line with this, erlotinib prevented the progression of cirrhosis in mice and rats and prevented even the development of HCC [91]. In an orthotopic model of HCC, gefitinib inhibited growth of the implanted tumors and intrahepatic metastasis by approximately 50\% [176], whereas in another orthotopic model of HCC, gefitinib significantly inhibited the growth of HCC, and the inhibitory effect could be enhanced by combining gefitinib with the cytotoxic agent cisplatin [177]. Gefitinib was able to reduce HCC-induced angiogenesis probably via phosphatase and tensin homolog (PTEN)/Akt signaling [178]. Further 
studies suggested that gefitinib is able to block the TNF- $\alpha$-induced transactivation of EGFR via TGF- $\alpha$ shedding by inhibiting MAPKs and Akt [179].

\section{EGFR Inhibitors in Human HCC}

As already mentioned, EGFR overexpression occurs in $68 \%$ of human HCCs correlating with aggressive tumors, metastasis, and poor patient survival [111-113]. EGFR inhibitors such as gefitinib, erlotinib or lapatinib, which also inhibits ErbB2, have been successful in the treatment of HCC in animal models $[91,172,175]$. Because of the promising results of EGFR inhibitors in animal models of HCC and their efficacy in other solid human tumors such as non-small cell lung carcinomas and colorectal cancers [180-182], it was hypothesized that targeting the EGFR signaling pathway might be beneficial also in HCC. Surprisingly, only modest results could be obtained in clinical studies. Whereas lapatinib and gefitinib treatment were not efficient in the therapy of HCC [183-185], erlotinib caused moderate effects when applied as a single agent $[184,186,187]$. Cetuximab demonstrated no antitumor activity in HCC when applied as a single agent $[184,188,189]$, but elicited some activity in combination with gemcitabine and oxaliplatin in poor prognosis patients [190]. Erlotinib has been tested in combination with the angiogenesis inhibitor bevacizumab in advanced HCC and showed modest activity [191,192] in two studies, but significant and clinically meaningful activity in another trial [193]. Sorafenib, a multikinase inhibitor for vascular endothelial growth factor receptor (VEGFR), PDGFR and Raf) and gefitinib significantly inhibited tumor growth in HCC tumor xenografts in mice [194]. Sorafenib has also shown clinical benefit in advanced HCC. However the SEARCH (Sorafenib and Erlotinib, a Randomized Trial Protocol for the Treatment of Patients With Hepatocellular Carcinoma) trial, the only phase III clinical trial including an EGFR inhibitor, was unable to reveal an improvement in survival of patients with advanced HCC by combining erlotinib and sorafenib [195].

In view of these results, the importance of specifically targeting EGFR signaling in HCCs remains questionable. However, the distinct roles of EGFR in hepatocytes and Kupffer cells during hepatocarcinogenesis discovered by our group possibly shed light on the so far observed treatment failures of HCC with EGFR inhibitors. Indeed, we found that deletion of EGFR in hepatocytes led to increased formation of HCC, whereas deletion of EGFR in Kupffer cells and/or liver macrophages severely reduced development of HCC in mice [76] (Figure 1d). Analysis of two different patient cohorts, one from China with mostly HBV-positive HCCs and one from Europe with mostly alcohol-, HCV- or NASH-induced HCC, which underwent liver transplantation, revealed that EGFR was expressed in liver macrophages of about $45 \%$ of HCC patients. Interestingly, EGFR positivity in liver macrophages correlated with poor prognosis with reduced disease free (DFS) and overall survival (OS) of patients [76]. Surprisingly, the expression levels of EGFR in tumor cells did not show any prognostic value for the DFS and OS of patients [76]. We also found that IL-6 levels were increased in the serum of HCC patients of the Asian cohort harboring EGFR-positive Kupffer cells in their tumors and correlating with HBV positivity [76]. Unfortunately, serum IL-6 levels could not be determined in the European cohort. Based on these results, we anticipate that only HCC patients with EGFR-positive macrophages in their tumors would benefit from anti-EGFR therapies, while a worse outcome would be expected in patients where the EGFR is expressed in tumor cells. However, this hypothesis needs to be further validated in clinical trials. Moreover, targeting exclusively EGFR-positive liver macrophages with EGFR inhibitors would be even preferable in HCC patients. Taken together, this study provides a possible explanation for the low success rate of EGFR inhibitors in unstratified patient populations of advanced stage HCC.

Many other possible explanations for treatment failure with EGFR inhibitors are discussed in the literature. One possible explanation for treatment failure could be that mutations of the kinase domain of EGFR do not play a significant role in the tumorigenesis of HCC as activating mutations have not been reported in human HCCs [196,197], whereas for example for non-small cell lung carcinomas the treatment response to gefitinib correlated with an activating mutation in the kinase domain [180]. Interestingly, also epithelial-to-mesenchymal transition (EMT) was examined as a marker 
for sensitivity or resistance of HCC to EGFR inhibitors. Hepatoma cell lines that were classified as epithelial due to their E-cadherin expression were sensitive to EGFR inhibitors, whereas hepatoma cell lines classified as mesenchymal (vimentin-positive) were resistant to EGFR inhibitors and displayed increased Akt and STAT3 phosphorylation. However, analysis of the EGFR pathway showed that EMT status was independent of EGFR expression or ERK activation [198]. Of note, resistance of human hepatoma cells was also associated with major vault protein (MVP) expression, a protein also known as lung-resistance related protein that is widely distributed in normal tissue and overexpressed in multidrug-resistant cancer cells. MVP decreased sensitivity to the EGFR inhibitor gefitinib via an increase of Akt signaling [199].

Many other growth factors and their receptors are deregulated in human HCC and directly or indirectly influence EGFR signaling. Simultaneous targeting of several growth factor pathways could increase the clinical benefit and reduce development of resistances to targeted therapies. Beside the TGF- $\alpha$ /EGFR signaling pathway, insulin like growth factor-2 (IGF2)/IGF-1R and hepatocyte growth factor (HGF)/c-Met are suggested to play important roles in the development of HCC [108]. Overexpression of IGF-1R was detected in 33\% of HCCs and increased activation of IGF-1R was observed in 52\% of tumors [200]. The proliferative action of IGF-2 in HCC cell lines required EGFR activation through the release of AR. Inhibition of the IGF-2/IGF-1R signaling pathway potentiated the anti-tumoral effect of gefinitib in HCC. Intriguingly, to overcome IGF-1R inhibition, hepatoma cells were able to activate ErbB3 in an EGFR-dependent manner [201]. These results suggest targeting EGFR and IGF-1R simultaneously in HCC. Furthermore, signaling via HGF/c-Met plays a key role in liver regeneration [202], as HGF is mitogenic for hepatocytes, which is suggested to be a secondary effect to increased processing of EGFR ligands such as TGF- $\alpha$. Furthermore, EGF and TGF- $\alpha$ were found to stimulate c-Met phosphorylation and nuclear accumulation of $\beta$-catenin through EGFR activation in hepatocarcinoma cells [203]. Neutralizing antibodies against TGF- $\alpha$ and/or EGFR could inhibit c-Met phosphorylation. These results suggest that c-Met phosphorylation in tumor cell lines is the result of EGFR activation [15] and promotes parallel inhibition of EGFR and c-Met to increase clinical benefit. In several carcinoma cell lines, but also in an HCC cell lines, HGF was recently found to inhibit EGFR tyrosine kinase activity and that this kinase-inactive EGFR stabilizes cancer-related proteins [204]. Noteworthy, sensitivity to gefitinib could be restored in an EGFR-mutated non-small cell lung carcinoma (NSCLC) cell line by the inhibition of the HGF/c-Met axis [204].

EGFR variant III (EGFRvIII) can be found in human HCC tissue [205], in the serum of HCC patients [206] and in numerous HCC cell lines, where it correlates with rapid cell growth and lower sensitivity to chemotherapeutics like 5-fluorouracil [207]. Treatment of EGFRvIII expressing HCC xenografts with the anti-EGFRvIII monoclonal antibody $\mathrm{CH} 12$ inhibited xenograft growth in vivo by suppressing tumor proliferation and angiogenesis and by reducing phosphorylation of constitutively active EGFRvIII, Akt, and ERK [208]. Furthermore, CH12 enhanced growth suppression conferred by 5-fluorouracil in HCC xenografts with EGFRvIII expression [209]. Additionally, CH12 was shown to synergize with sorafenib and strongly inhibit the tumor growth of HCC xenografts that expressed EGFRvIII via activation of several growth factor associated downstream signaling pathways [210]. These results suggest targeting EGFRvIII-positive HCCs with CH12 in combination with other targeted drugs as a new promising therapeutic agent.

\section{EGFR and Its Ligands in Hepatolithiasis and Cholangiocarcinoma}

Cholangiocarcinoma (CC) is a primary neoplasm arising from cholangiocytes. Although it is rare, CC is the second most common primary liver neoplasm [211]. Persistent inflammation in the biliary tract strongly predisposes to CC with IL-6 playing a key role during tumorigenesis. IL-6 overexpression increased gene expression and decreased the promoter methylation of EGFR [212]. EGFR overexpression was assessed in different studies with heterogeneous results ranging from $10 \%$ to $81 \%$ positivity for intrahepatic CC [213-218] and approximately $20 \%$ for extrahepatic CC [218-220]. In a study with 236 cases of CC, EGFR overexpression was associated with lymph node metastasis, 
tumor stage, lymphatic vessel invasion and perineural invasion in extrahepatic CC. A multivariate analysis revealed EGFR as a significant prognostic marker and a risk factor for tumor recurrence in intrahepatic CC [218]. A recent study showed that EGFR amplification and EGFR overexpression significantly correlated with one another and a multivariate analysis suggested EGFR overexpression being an independent prognostic factor in intrahepatic, but not extrahepatic CC [219]. Concerning the presence of EGFR mutations in CCs, studies have reported opposing results. Whereas one study did not find any somatic mutations of the EGFR gene in CC [221], others described somatic mutations in the tyrosine kinase domain of EGFR in a subpopulation of CC [222,223]. EGFR overexpression was also described for hepatolithiasis [224] and associated with the degree of differentiation from hepatolithiasis to intrahepatic CC and with the depth of invasion, which also correlated with poor prognosis [225]. Furthermore, the EMT-like phenotype of cholangiocytes of small bile ducts correlated with strong EGFR expression in the ductular epithelium of hepatolithiasis [226].

In a study with 100 CC patients, cytoplasmic E-cadherin location was associated with EGFR overexpression. In CC cell lines, EGF decreased the expression of E-cadherin and scattering of CC cells, which displayed disrupted adherens junctions. In xenograft tumors, gefitinib treatment restored the membranous expression of E-cadherin [227]. These results suggest that the EGF/EGFR axis triggers EMT in CC cells, highlighting the role of EGFR in CC development. Furthermore, in biliary cancer cells, loss of EBP50, a $\beta$-catenin-associating protein, was shown to stimulate EGFR activity to induce EMT-associated features, along with E-cadherin and cytokeratin-19 reduction and induction of the E-cadherin transcriptional repressor Slug as well as loss of cell polarity [228]. EGFR further mediated the phosphorylation of the cytoplasmic tail of the transmembrane mucin MUC1 and this enhanced its affinity for $\beta$-catenin potentially correlating with a decrease in cell adhesion and an increase in invasiveness of tumor cells $[229,230]$. MUC1 was also described to modulate TGF- $\alpha$-dependent cancer progression and to regulate EGFR stability upon activation and might induce transformation through the inhibition of EGFR degradation [231]. Another study showed that annexin A8, which is highly expressed in CCs but downregulated upon tumor dedifferentiation, is downregulated by activation of the EGF/EGFR system via PI3K and Akt and that this correlated with EMT in CC cells [232].

In a human intrahepatic CC cell line, downregulation of miR-376c, which is suggested to function as a tumor suppressor, accelerated EGF-dependent migration through its direct target growth factor receptor bound protein 2 (GRB2) [233]. Interestingly, in the human intrahepatic CC RBE cell line, EGFR degradation was impaired, which was associated with hypo-phosphorylation of Tyr1045 and with enhanced recycling of EGFR to the cell membrane, indicating that upregulation of Tyr1045 phosphorylation might be a beneficial molecular alteration in EGFR-targeted therapy [234]. A pro-tumorigenic role for the HB-EGF/EGFR axis was recently described in intrahepatic CC. Hepatic myofibroblasts were shown to crosstalk with CC cells and to contribute to tumorigenesis via activation of the HB-EGF/EGFR axis, which could be inhibited by gefitinib [235]. The effect of cetuximab was assessed in two different CC cell lines. Cetuximab did not inhibit cell growth in CC cells carrying a heterozygous Kirsten rat sarcoma viral oncogene homolog (KRAS) mutation, but had a dose-dependent effect on growth of CC cells displaying the KRAS wild-type [236]. In a rat model of chemical carcinogenesis, EGFR and STAT3 signaling pathways were suggested to contribute to intrahepatic CC. Mechanistically, high STAT3 activity was suggested to be the result of high EGFR activity, which was triggered by TGF- $\alpha$ [237]. In vitro, EGFR inhibition or dual inhibition of EGFR and ErbB2 effectively suppressed cell growth and induced apoptosis in human and rodent biliary cancer cell lines and these inhibitors have also been shown to successfully block tumor growth in xenografted athymic nude mice [238]. Given the important role of EGFR in CC development, the employment of EGFR inhibitors was thought to be a promising strategy. However, tyrosine kinase inhibitor therapy showed only modest benefit in certain CC patients [185,239-244].

Conjugated bile acids have been described to be increased in CC patient serum [245], which might correlate with biliary tract tumorigenesis [246,247]. In human cholangiocyte cell lines, bile acids were shown to transactivate EGFR in a ligand-dependent manner via a TGF- $\alpha$, which could be blocked by 
an MMP inhibitor [23]. Conjugated bile acids in contrast to free bile acids enhanced the activation of NF-KB, which was associated with elevated IL-6 levels and cyclooxygenase (COX-2) expression and inhibition of the turnover of the potent anti-apoptotic protein myeloid cell leukemia 1 (Mcl-1) via an EGFR/Raf1-dependent mechanism [248-251]. A comparable mechanism has been described in rat HSCs, indicating that bile acids might contribute to enhanced survival and proliferation of myofibroblasts in tumor stroma of CCs [252]. In human CC cells, a crosstalk between COX-2 derived prostaglandin $\mathrm{E}_{2}\left(\mathrm{PGE}_{2}\right)$ and EGFR has been demonstrated [253]. EGF stimulation increased cell growth and EGFR kinase inhibitors could successfully decrease COX-2 levels in cultured human CC cells and attenuate cellular growth. This study further demonstrated that CC cells exhibit sustained EGFR activation resulting in extended p42/44 MAPK activation due to defective receptor internalization [254]. These results suggest a positive regulatory loop between EGFR and COX-2.

\section{EGFR and Its Ligands in Hepatic Progenitor Cells}

During chronic viral hepatitis, alcoholic liver diseases, and non-alcoholic fatty liver disease, hepatic progenitor cells (HPC, also called oval cells) that persist in adulthood, play an important role in the regeneration of hepatocytes and cholangiocytes [255-258]. Oval cells were described to express EGFR and in vivo administration of EGF and HGF enhanced their mitogenic potential after carcinogen administration [259], which highlights the relevance of EGFR in liver progenitor cells. EGFR and c-Met were shown to increase the self-renewal of HPCs through activation of ERK. In adult HPCs, c-Met was a strong inducer of hepatocyte differentiation via Akt and STAT3, whereas EGFR selectively induced NOTCH1 to promote cholangiocyte specification and branching while suppressing hepatocyte commitment. Interestingly, conditional loss of EGFR in the liver rather facilitated than suppressed progenitor-mediated liver regeneration by switching the progenitor cell differentiation to the hepatocyte lineage [260]. EGF administration could significantly increase the proliferation and colony formation of a Sca-1-positive HPC subpopulation, while stimulating the phosphorylation of ERK1/2 and the induction of cyclin D1 [261]. However, while one study described no EGFR expression on carcinogen-treated oval cells of rat liver [262], another study revealed that TGF- $\alpha$ and EGFR were significantly elevated early when oval cells were proliferating. However, expression decreased after a month and remained low until the development of liver tumors [263-265]. EGFR-ligand-mediated autocrine mechanisms have been suggested, based on the detection of transcripts of EGFR ligands in oval cells during liver regeneration, but are not yet fully understood [264]. Interestingly, EGF, AR, BTC, HB-EGF and TGF- $\alpha$ were mitogenic for murine oval cell lines, whereas transforming growth factor $\beta 1$ (TGF- $\beta 1$ ), TGF- $\beta 2$ and TGF- $\beta 3$ inhibited mitogenesis and induced apoptosis. Combination of EGF ligands and TGF- $\beta$ factors led to scattering in tissue culture and morphological differentiation in Matrigel [266]. Furthermore, TGF- $\beta 1$ is an important fibrogenic factor [267] that can induce differentiation of hepatic progenitors into tumor initiating cells via EMT $[268,269]$. In fetal primary hepatocytes, EGF prevented TGF- $\beta$-induced cell death and blocked c-fos induction associated with the apoptotic process induced by TGF- $\beta$ in these cells [270]. In murine adult hepatic oval cells, EGF suppressed TGF- $\beta$-induced apoptosis [271], whereas EGFR inhibition increased TGF- $\beta$-induced apoptosis [272], suggesting that constitutively active EGFR might promote proliferation and survival of hepatic progenitor cells. EGF was further shown to suppress and revert TGF- $\beta$-1-induced EMT of hepatic progenitors [272]. Taken together, these data highlight the important role of EGFR downstream signaling pathways in regulating the liver progenitor cell compartment.

\section{Conclusions}

Loss of function studies have shown that EGFR and its ligands are not crucial for embryonic liver development. However, EGFR ligands are potent mitogens for cultured hepatocytes. Studies of partial hepatectomy have highlighted the important role of EGFR during liver regeneration and have shown that EGFR is a critical regulator of hepatocyte proliferation in the initial phase of liver regeneration. Interestingly, EGFR ligands have different functions during liver regeneration and loss 
of some EGFR ligands impairs liver regeneration more severely than loss of others, which is probably attributable to redundant expression. In two different experimental models of acute liver damage, the EGFR signaling system was clearly demonstrated to be hepatoprotective. EGFR ligands exert also different functions during fibrosis, as EGF was shown to be anti-fibrogenic in toxic fibrosis, whereas AR was suggested to have a pro-fibrogenic role. Intriguingly, loss of EGFR alone had no effect on the regenerative response after $\mathrm{CCl}_{4}$-induced toxic liver fibrosis. In addition, in other experimental models of liver injury, like biliary fibrosis or NASH, deletion of different EGFR ligands gave opposing results. This further highlights how diverse different EGFR ligands exert their functions by probably activating different EGFR downstream signaling pathways.

However, these results show that the EGFR system plays an important role during acute and chronic liver diseases, which are the pre-stages on the way to hepatocellular carcinoma development. $\mathrm{HBV}$ and $\mathrm{HCV}$ infection are important risk factors for liver cancer. The HBV $x$ gene and protein were suggested to be involved in the pathogenesis of HBV-induced hepatocellular carcinoma formation. While the $x$-gene product was demonstrated to be capable of inducing EGFR overexpression, the HBV-encoded $x$ protein indirectly downregulated EGFR expression in HCC cells. Moreover, the EGFR system was suggested to contribute to immune tolerance and viral amplification after HBV infection. Beside hepatitis $B$ virus infection, the main risk factors for HCC include hepatitis $C$ virus infection. Studies also highlighted an important role of EGFR during HCV entry into the target cell and suggested EGFR inhibitors to be successful inhibitors of viral entry and viral replication. For AR it was shown that HCV infection can lead to an increase in its expression in hepatocytes, and it is believed that AR is responsible for efficient $\mathrm{HCV}$ assembly and virion release. Furthermore, AR protected infected cells from HCV-induced cell death and facilitated liver cirrhosis and HCC progression, which indicates a pro-tumorigenic role for AR in HCV-induced HCC.

Besides HBV and HCV infection, other risk factors for liver cancer in Western countries include obesity, type II diabetes, cirrhosis related to heavy alcohol consumption and non-alcoholic liver disease including NASH. In human HCCs, overexpression of EGFR occurs in $68 \%$ of HCCs correlating with aggressive tumors, metastasis, and poor patient survival and EGFR ligands were frequently found overexpressed. Inhibiting EGFR either with small molecule inhibitors such as the EGFR tyrosine kinase inhibitors gefitinib or erlotinib or with anti-EGFR antibodies such as cetuximab has given promising results in HCC cell lines and in animal studies. Surprisingly, only modest results could be obtained with EGFR inhibitors in clinical studies. A major drawback in the conductance of therapeutic studies for HCC has been the lack of patient stratification according to biomarkers usually requiring tissue biopsy, which is no longer performed in most centers since the diagnosis is based on radiological imaging criteria. For example, a recent study with the c-Met inhibitor tivantinib nearly failed over significance in preventing tumor progression, since overall only a very moderate effect could be seen. However, closer patient stratification revealed that c-Met high expressing patients showed a survival benefit, while c-Met low patients did not respond to the treatment of tivantinib [273]. A similar patient stratification has not yet been performed in human HCC trials using gefitinib or erlotinib.

The role of EGFR in HCC seems to be more complex than initially believed, particularly because EGFR expression is not restricted to tumor cells, but EGFR was also demonstrated to be expressed on sinusoidal endothelial cells, as well as on Kupffer cells and liver macrophages. Expression of EGFR on liver macrophages correlated with poor prognosis in patient survival. In view of this pivotal role of EGFR during inflammation-driven HCC formation, EGFR-positive Kupffer cells might be a useful prognostic marker and could represent a new therapeutic target for HCC. Since our findings demonstrate that genetic deletion of EGFR in macrophages is sufficient to inhibit HCC development, future studies should consider targeting anti-EGFR therapies specifically to macrophages. Clinical follow-up studies will have to reevaluate the use of EGFR inhibitors in HCC and restrict it to patients with EGFR expression in liver macrophages, since we would expect a worse outcome in patients where the EGFR is expressed in tumor cells. Many other growth factors and their receptors are deregulated in human HCC and directly or indirectly influence EGFR signaling. Simultaneous 
targeting of several growth factor pathways could increase the clinical benefit and reduce development of resistances to targeted therapies. Since in tumor cell lines, c-Met phosphorylation can result from EGFR activation [15], parallel inhibition of EGFR and c-Met could increase the clinical benefit due to synergistic effects of tivatinib and erlotinib or gefitinib. Since the anti-EGFRvIII monoclonal antibody $\mathrm{CH} 12$ was shown to synergize with sorafenib and strongly inhibit the tumor growth of HCC xenografts [210], a possible synergistic effect with erlotinib or gefitinib would need to be evaluated in patients with EGFRvIII expression in HCC biopsy or patient serum.

EGFR overexpression was also found in CC and was associated with lymph node metastasis, tumor stage, lymphatic vessel and perineural invasion and revealed EGFR as an independent significant prognostic marker and a risk factor for tumor recurrence in CC. Studies suggest that the EGF/EGFR axis triggers EMT in CC cells. Furthermore, a pro-tumorigenic role for the HB-EGF/EGFR axis was described and indirect modulation of TGF- $\alpha$ was associated with CC progression. Despite the apparent important role of EGFR in CC development, EGFR inhibitor therapy revealed also only modest benefit in CC patients and it remains to be investigated whether, similar to HCCs, the EGFR plays a tumorigenic function in non-tumor cells.

Taken together, there is definitive need for better biomarkers to classify patients into subpopulations that could benefit from anti-EGFR targeted therapies and to closely monitor patient responses. Further work is needed to molecularly dissect different types of liver cancer and to find effective therapies against this deadly disease.

Acknowledgments: This work was supported by the Austrian Science Fund (Fonds zur Förderung der wissenschaftlichen Forschung (FWF)) by the following grants: special research programme (Spezialforschungsbereich (SFB)) F3518-B20, P25925 and the FWF-Doktoratskolleg (DK) W1212. We thank Thomas Bauer for graphical artwork (Figures 1 and 2). We thank Robert Eferl for critical reading of the manuscript.

Authors Contributions: Karin Komposch wrote the manuscript under the supervision of Maria Sibilia, who assisted in reviewing and rewriting the manuscript.

Conflicts of Interest: The authors declare no conflict of interest.

\section{Abbreviations}

ADAM: a disintegrin and metalloproteinases; ALD: alcoholic liver disease; ALT: alanine transaminase; AR: amphiregulin; AST: aspartate transaminase; BDL: bile duct ligation; BMP-7: bone morphogenetic protein 7; BTC: betacellulin; CC: cholangiocarcinoma; $\mathrm{CCl}_{4}$ : carbon tetrachloride; $\mathrm{CHC}$ : chronic hepatitis C; CHX: cycloheximide; c-Met: hepatocyte growth factor receptor; COX-2: cyclooxygenase; CTGF: connective tissue growth factor; DDC: 3,5-Diethoxycarbonyl-1,4-dihydrocollidine; DEN: Diethylnitrosamine; DFS: disease free survival; ECM: extracellular matrix; EGF: epidermal growth factor; EGFR: epidermal growth factor receptor; EMT: epithelial-to-mesenchymal transition; EPGN: epigen; EREG: epiregulin; FGF-19: fibroblast growth factor 19; GEMMs: genetically engineered mouse models; GH: growth hormone; GPCRs: G-protein-coupled receptors; Grb2: growth factor receptor-bound protein 2; HB-EGF: heparin-binding EGF; HBsAg: hepatitis B surface antigen; HBV: hepatitis B virus; HCC: hepatocellular carcinoma; HCV: hepatitis C virus; HRas: Harvey rat sarcoma viral oncogene homolog; IGF1-R: insulin-like growth factor 1 receptor; IKK: inhibitor of KB (IкB) kinase; JNK: c-Jun N-terminal kinase; KRAS: Kirsten rat sarcoma viral oncogene homolog; MCD: methionine- and choline-deficient; Mcl-1: myeloid cell leukemia 1; Mig-6: mitogen-inducible gene-6; MMP: matrix metallopeptidase; mRNA: messenger RNA; mTOR: mechanistic target of rapamycin; MUC: mucin; MVP: major vault protein; NAPDH: nicotinamide adenine dinucleotide phosphate-oxidase; NF-kB: nuclear factor 'kappa-light-chain-enhancer' of activated B-cells; NASH: non-alcoholic steatohepatitis; NSCLC: non-small cell lung carcinoma; OS: overall survival; PDGFR: platelet-derived growth factor receptor; PI3K: phosphatidylinositol-3-kinase; PLC $\gamma$ : phospholipase C $\gamma$; polyI:C: polyinosinic:polycytidylic acid; PTEN: phosphatase and tensin homolog; RTK: receptor tyrosine kinases; SH2: Src-homology 2 domains; SHC: SHC-transforming protein; STAT: signal-transducer and activator of transcription; TACE: TNF- $\alpha$-converting enzyme; TGF: transforming 
growth factor; TNF- $\alpha$ : tumor necrosis factor $\alpha$; Treg: regulatory T cells; VEGFR: vascular endothelial growth factor receptor.

\section{References}

1. Schlessinger, J. Ligand-induced, receptor-mediated dimerization and activation of EGF receptor. Cell 2002, 110, 669-672. [CrossRef]

2. Jorissen, R.N.; Walker, F.; Pouliot, N.; Garrett, T.P.; Ward, C.W.; Burgess, A.W. Epidermal growth factor receptor: Mechanisms of activation and signalling. Exp. Cell Res. 2003, 284, 31-53. [CrossRef]

3. Citri, A.; Yarden, Y. EGF-ErbB signalling: Towards the systems level. Nat. Rev. Mol. Cell Biol. 2006, 7, 505-516. [CrossRef] [PubMed]

4. Schneider, M.R.; Wolf, E. The epidermal growth factor receptor ligands at a glance. J. Cell. Physiol. 2009, 218, 460-466. [CrossRef] [PubMed]

5. Normanno, N.; de Luca, A.; Bianco, C.; Strizzi, L.; Mancino, M.; Maiello, M.R.; Carotenuto, A.; de Feo, G.; Caponigro, F.; Salomon, D.S. Epidermal growth factor receptor (EGFR) signaling in cancer. Gene 2006, 366, 2-16. [CrossRef] [PubMed]

6. Massague, J.; Pandiella, A. Membrane-anchored growth factors. Annu. Rev. Biochem. 1993, 62, 515-541. [CrossRef] [PubMed]

7. Ohtsu, H.; Dempsey, P.J.; Eguchi, S. ADAMs as mediators of EGF receptor transactivation by $\mathrm{g}$ protein-coupled receptors. Am. J. Physiol. Cell Physiol. 2006, 291, C1-C10. [CrossRef] [PubMed]

8. Blobel, C.P. ADAMs: Key components in EGFR signalling and development. Nat. Rev. Mol. Cell Biol. 2005, 6, 32-43. [CrossRef] [PubMed]

9. Sahin, U.; Blobel, C.P. Ectodomain shedding of the EGF-receptor ligand epigen is mediated by ADAM17. FEBS Lett. 2007, 581, 41-44. [CrossRef] [PubMed]

10. Yarden, Y.; Sliwkowski, M.X. Untangling the ErbB signalling network. Nat. Rev. Mol. Cell Biol. 2001, 2, 127-137. [CrossRef] [PubMed]

11. Hynes, N.E.; Lane, H.A. ErbB receptors and cancer: The complexity of targeted inhibitors. Nat. Rev. Cancer 2005, 5, 341-354. [CrossRef] [PubMed]

12. Saito, Y.; Haendeler, J.; Hojo, Y.; Yamamoto, K.; Berk, B.C. Receptor heterodimerization: Essential mechanism for platelet-derived growth factor-induced epidermal growth factor receptor transactivation. Mol. Cell. Biol. 2001, 21, 6387-6394. [CrossRef] [PubMed]

13. Habib, A.A.; Hognason, T.; Ren, J.; Stefansson, K.; Ratan, R.R. The epidermal growth factor receptor associates with and recruits phosphatidylinositol 3-kinase to the platelet-derived growth factor $\beta$ receptor. J. Biol. Chem. 1998, 273, 6885-6891. [CrossRef] [PubMed]

14. Morgillo, F.; Woo, J.K.; Kim, E.S.; Hong, W.K.; Lee, H.Y. Heterodimerization of insulin-like growth factor receptor/epidermal growth factor receptor and induction of survivin expression counteract the antitumor action of erlotinib. Cancer Res. 2006, 66, 10100-10111. [CrossRef] [PubMed]

15. Jo, M.; Stolz, D.B.; Esplen, J.E.; Dorko, K.; Michalopoulos, G.K.; Strom, S.C. Cross-talk between epidermal growth factor receptor and c-Met signal pathways in transformed cells. J. Biol. Chem. 2000, 275, 8806-8811. [CrossRef] [PubMed]

16. Burova, E.; Vassilenko, K.; Dorosh, V.; Gonchar, I.; Nikolsky, N. Interferon $\gamma$-dependent transactivation of epidermal growth factor receptor. FEBS Lett. 2007, 581, 1475-1480. [CrossRef] [PubMed]

17. Gonzalez, L.; Diaz, M.E.; Miquet, J.G.; Sotelo, A.I.; Fernandez, D.; Dominici, F.P.; Bartke, A.; Turyn, D. Gh modulates hepatic epidermal growth factor signaling in the mouse. J. Endocrinol. 2010, 204, 299-309. [CrossRef] [PubMed]

18. Moro, L.; Dolce, L.; Cabodi, S.; Bergatto, E.; Boeri Erba, E.; Smeriglio, M.; Turco, E.; Retta, S.F.; Giuffrida, M.G.; Venturino, M.; et al. Integrin-induced epidermal growth factor (EGF) receptor activation requires c-Src and p130cas and leads to phosphorylation of specific EGF receptor tyrosines. J. Biol. Chem. 2002, 277, 9405-9414. [CrossRef] [PubMed]

19. Fischer, O.M.; Hart, S.; Gschwind, A.; Ullrich, A. EGFR signal transactivation in cancer cells. Biochem. Soc. Trans. 2003, 31, 1203-1208. [CrossRef] [PubMed]

20. Almendro, V.; Garcia-Recio, S.; Gascon, P. Tyrosine kinase receptor transactivation associated to G protein-coupled receptors. Curr. Drug Targets 2010, 11, 1169-1180. [CrossRef] [PubMed] 
21. Liebmann, C. EGF receptor activation by GPCRs: An universal pathway reveals different versions. Mol. Cell. Endocrinol. 2011, 331, 222-231. [CrossRef] [PubMed]

22. Yamauchi, T.; Ueki, K.; Tobe, K.; Tamemoto, H.; Sekine, N.; Wada, M.; Honjo, M.; Takahashi, M.; Takahashi, T.; Hirai, H.; et al. Tyrosine phosphorylation of the EGF receptor by the kinase Jak2 is induced by growth hormone. Nature 1997, 390, 91-96. [PubMed]

23. Werneburg, N.W.; Yoon, J.H.; Higuchi, H.; Gores, G.J. Bile acids activate EGF receptor via a TGF- $\alpha$-dependent mechanism in human cholangiocyte cell lines. Am. J. Physiol. Gastrointest. Liver Physiol. 2003, 285, G31-G36. [CrossRef] [PubMed]

24. Sibilia, M.; Kroismayr, R.; Lichtenberger, B.M.; Natarajan, A.; Hecking, M.; Holcmann, M. The epidermal growth factor receptor: From development to tumorigenesis. Differentiation 2007, 75, 770-787. [CrossRef] [PubMed]

25. Luetteke, N.C.; Qiu, T.H.; Fenton, S.E.; Troyer, K.L.; Riedel, R.F.; Chang, A.; Lee, D.C. Targeted inactivation of the EGF and amphiregulin genes reveals distinct roles for EGF receptor ligands in mouse mammary gland development. Development 1999, 126, 2739-2750. [PubMed]

26. Lee, D.; Pearsall, R.S.; Das, S.; Dey, S.K.; Godfrey, V.L.; Threadgill, D.W. Epiregulin is not essential for development of intestinal tumors but is required for protection from intestinal damage. Mol. Cell. Biol. 2004, 24, 8907-8916. [CrossRef] [PubMed]

27. Jackson, L.F.; Qiu, T.H.; Sunnarborg, S.W.; Chang, A.; Zhang, C.; Patterson, C.; Lee, D.C. Defective valvulogenesis in HB-EGF and TACE-null mice is associated with aberrant bmp signaling. EMBO J. 2003, 22, 2704-2716. [CrossRef] [PubMed]

28. Dahlhoff, M.; Schafer, M.; Wolf, E.; Schneider, M.R. Genetic deletion of the EGFR ligand epigen does not affect mouse embryonic development and tissue homeostasis. Exp. Cell Res. 2013, 319, 529-535. [CrossRef] [PubMed]

29. Iwamoto, R.; Yamazaki, S.; Asakura, M.; Takashima, S.; Hasuwa, H.; Miyado, K.; Adachi, S.; Kitakaze, M.; Hashimoto, K.; Raab, G.; et al. Heparin-binding EGF-like growth factor and ErbB signaling is essential for heart function. Proc. Natl. Acad. Sci. USA 2003, 100, 3221-3226. [CrossRef] [PubMed]

30. Luetteke, N.C.; Qiu, T.H.; Peiffer, R.L.; Oliver, P.; Smithies, O.; Lee, D.C. TGF $\alpha$ deficiency results in hair follicle and eye abnormalities in targeted and waved-1 mice. Cell 1993, 73, 263-278. [CrossRef]

31. Mann, G.B.; Fowler, K.J.; Gabriel, A.; Nice, E.C.; Williams, R.L.; Dunn, A.R. Mice with a null mutation of the TGF $\alpha$ gene have abnormal skin architecture, wavy hair, and curly whiskers and often develop corneal inflammation. Cell 1993, 73, 249-261. [CrossRef]

32. Miettinen, P.J.; Berger, J.E.; Meneses, J.; Phung, Y.; Pedersen, R.A.; Werb, Z.; Derynck, R. Epithelial immaturity and multiorgan failure in mice lacking epidermal growth factor receptor. Nature 1995, 376, 337-341. [CrossRef] [PubMed]

33. Sibilia, M.; Wagner, E.F. Strain-dependent epithelial defects in mice lacking the EGF receptor. Science 1995, 269, 234-238. [CrossRef] [PubMed]

34. Threadgill, D.W.; Dlugosz, A.A.; Hansen, L.A.; Tennenbaum, T.; Lichti, U.; Yee, D.; LaMantia, C.; Mourton, T.; Herrup, K.; Harris, R.C.; et al. Targeted disruption of mouse EGF receptor: Effect of genetic background on mutant phenotype. Science 1995, 269, 230-234. [CrossRef] [PubMed]

35. Natarajan, A.; Wagner, B.; Sibilia, M. The EGF receptor is required for efficient liver regeneration. Proc. Natl. Acad. Sci. USA 2007, 104, 17081-17086. [CrossRef] [PubMed]

36. Taub, R. Liver regeneration: From myth to mechanism. Nat. Rev. Mol. Cell Biol. 2004, 5, 836-847. [CrossRef] [PubMed]

37. Carver, R.S.; Stevenson, M.C.; Scheving, L.A.; Russell, W.E. Diverse expression of ErbB receptor proteins during rat liver development and regeneration. Gastroenterology 2002, 123, 2017-2027. [CrossRef] [PubMed]

38. Bucher, N.L.; Patel, U.; Cohen, S. Hormonal factors concerned with liver regeneration. In Hepatotrophic Factors; Elsevier Excerpta Media: New York, NY, USA, 1978; pp. 95-107.

39. Hashimoto, M.; Kothary, P.C.; Eckhauser, F.E.; Raper, S.E. Treatment of cirrhotic rats with epidermal growth factor and insulin accelerates liver DNA synthesis after partial hepatectomy. J. Gastroenterol. Hepatol. 1998, 13, 1259-1265. [CrossRef] [PubMed]

40. Ito, N.; Kawata, S.; Tamura, S.; Kiso, S.; Tsushima, H.; Damm, D.; Abraham, J.A.; Higashiyama, S.; Taniguchi, N.; Matsuzawa, Y. Heparin-binding EGF-like growth factor is a potent mitogen for rat hepatocytes. Biochem. Biophys. Res. Commun. 1994, 198, 25-31. [CrossRef] [PubMed] 
41. Block, G.D.; Locker, J.; Bowen, W.C.; Petersen, B.E.; Katyal, S.; Strom, S.C.; Riley, T.; Howard, T.A.; Michalopoulos, G.K. Population expansion, clonal growth, and specific differentiation patterns in primary cultures of hepatocytes induced by HGF/SF, EGF and TGF $\alpha$ in a chemically defined (HGM) medium. J. Cell Biol. 1996, 132, 1133-1149. [CrossRef] [PubMed]

42. Fausto, N.; Laird, A.D.; Webber, E.M. Liver regeneration. 2. Role of growth factors and cytokines in hepatic regeneration. FASEB J. 1995, 9, 1527-1536. [PubMed]

43. Berasain, C.; Garcia-Trevijano, E.R.; Castillo, J.; Erroba, E.; Lee, D.C.; Prieto, J.; Avila, M.A. Amphiregulin: An early trigger of liver regeneration in mice. Gastroenterology 2005, 128, 424-432. [CrossRef] [PubMed]

44. Draghi, E.; Armato, U.; Andreis, P.G.; Mengato, L. The stimulation by epidermal growth factor (urogastrone) of the growth of neonatal rat hepatocytes in primary tissue culture and its modulation by serum and associated pancreatic hormones. J. Cell. Physiol. 1980, 103, 129-147. [CrossRef] [PubMed]

45. De Juan, C.; Benito, M.; Alvarez, A.; Fabregat, I. Differential proliferative response of cultured fetal and regenerating hepatocytes to growth factors and hormones. Exp. Cell Res. 1992, 202, 495-500. [CrossRef]

46. McGowan, J.A.; Strain, A.J.; Bucher, N.L. DNA synthesis in primary cultures of adult rat hepatocytes in a defined medium: Effects of epidermal growth factor, insulin, glucagon, and cyclic-AMP. J. Cell. Physiol. 1981, 108, 353-363. [CrossRef] [PubMed]

47. Komurasaki, T.; Toyoda, H.; Uchida, D.; Nemoto, N. Mechanism of growth promoting activity of epiregulin in primary cultures of rat hepatocytes. Growth Factors 2002, 20, 61-69. [CrossRef] [PubMed]

48. Toyoda, H.; Komurasaki, T.; Uchida, D.; Takayama, Y.; Isobe, T.; Okuyama, T.; Hanada, K. Epiregulin. A novel epidermal growth factor with mitogenic activity for rat primary hepatocytes. J. Biol. Chem. 1995, 270, 7495-7500. [PubMed]

49. Webber, E.M.; FitzGerald, M.J.; Brown, P.I.; Bartlett, M.H.; Fausto, N. Transforming growth factor- $\alpha$ expression during liver regeneration after partial hepatectomy and toxic injury, and potential interactions between transforming growth factor- $\alpha$ and hepatocyte growth factor. Hepatology 1993, 18, 1422-1431. [CrossRef] [PubMed]

50. Kiso, S.; Kawata, S.; Tamura, S.; Higashiyama, S.; Ito, N.; Tsushima, H.; Taniguchi, N.; Matsuzawa, Y. Role of heparin-binding epidermal growth factor-like growth factor as a hepatotrophic factor in rat liver regeneration after partial hepatectomy. Hepatology 1995, 22, 1584-1590. [CrossRef]

51. Lin, X.M.; Liu, Y.B.; Zhou, F.; Wu, Y.L.; Chen, L.; Fang, H.Q. Expression of tumor necrosis factor- $\alpha$ converting enzyme in liver regeneration after partial hepatectomy. World J. Gastroenterol. 2008, 14, 1353-1357. [CrossRef] [PubMed]

52. Mitchell, C.; Nivison, M.; Jackson, L.F.; Fox, R.; Lee, D.C.; Campbell, J.S.; Fausto, N. Heparin-binding epidermal growth factor-like growth factor links hepatocyte priming with cell cycle progression during liver regeneration. J. Biol. Chem. 2005, 280, 2562-2568. [CrossRef] [PubMed]

53. Russell, W.E.; Kaufmann, W.K.; Sitaric, S.; Luetteke, N.C.; Lee, D.C. Liver regeneration and hepatocarcinogenesis in transforming growth factor- $\alpha$-targeted mice. Mol. Carcinog. 1996, 15, 183-189. [CrossRef]

54. Kokudo, N.; Kothary, P.C.; Eckhauser, F.E.; Raper, S.E. Transforming growth factor- $\alpha$ (TGF- $\alpha$ ) improves hepatic DNA synthesis after hepatectomy in cirrhotic rats. J. Surg. Res. 1992, 52, 648-655. [CrossRef]

55. Liu, Q.; Rehman, H.; Krishnasamy, Y.; Haque, K.; Schnellmann, R.G.; Lemasters, J.J.; Zhong, Z. Amphiregulin stimulates liver regeneration after small-for-size mouse liver transplantation. Am. J. Transpl. 2012, 12, 2052-2061. [CrossRef] [PubMed]

56. Kosone, T.; Takagi, H.; Horiguchi, N.; Kakizaki, S.; Sato, K.; Watanabe, Y.; Mori, M. Transforming growth factor- $\alpha$ accelerates hepatocyte repopulation after hepatocyte transplantation. J. Gastroenterol. Hepatol. 2008, 23, 260-266. [CrossRef] [PubMed]

57. Kiso, S.; Kawata, S.; Tamura, S.; Inui, Y.; Yoshida, Y.; Sawai, Y.; Umeki, S.; Ito, N.; Yamada, A.; Miyagawa, J.; et al. Liver regeneration in heparin-binding EGF-like growth factor transgenic mice after partial hepatectomy. Gastroenterology 2003, 124, 701-707. [CrossRef] [PubMed]

58. Noguchi, S.; Ohba, Y.; Oka, T. Influence of epidermal growth factor on liver regeneration after partial hepatectomy in mice. J. Endocrinol. 1991, 128, 425-431. [CrossRef] [PubMed]

59. Jones, D.E., Jr.; Tran-Patterson, R.; Cui, D.M.; Davin, D.; Estell, K.P.; Miller, D.M. Epidermal growth factor secreted from the salivary gland is necessary for liver regeneration. Am. J. Physiol. 1995, 268, G872-G878. [PubMed] 
60. Lambotte, L.; Saliez, A.; Triest, S.; Maiter, D.; Baranski, A.; Barker, A.; Li, B. Effect of sialoadenectomy and epidermal growth factor administration on liver regeneration after partial hepatectomy. Hepatology 1997, 25, 607-612. [CrossRef] [PubMed]

61. Noguchi, S.; Ohba, Y.; Oka, T. The role of transcription and messenger RNA stability in the regulation of epidermal growth factor receptor gene expression in regenerating mouse liver. Hepatology 1992, 15, 88-96. [CrossRef] [PubMed]

62. Scheving, L.A.; Zhang, X.; Stevenson, M.C.; Threadgill, D.W.; Russell, W.E. Loss of hepatocyte EGFR has no effect alone but exacerbates carbon tetrachloride-induced liver injury and impairs regeneration in hepatocyte Met-deficient mice. Am. J. Physiol. Gastrointest. Liver Physiol. 2015, 308, G364-G377. [CrossRef] [PubMed]

63. Lopez-Luque, J.; Caballero-Diaz, D.; Martinez-Palacian, A.; Roncero, C.; Moreno-Caceres, J.; Garcia-Bravo, M.; Grueso, E.; Fernandez, A.; Crosas-Molist, E.; Garcia-Alvaro, M.; et al. Dissecting the role of the epidermal growth factor receptor catalytic activity during liver regeneration and hepatocarcinogenesis. Hepatology 2015. [CrossRef] [PubMed]

64. Paranjpe, S.; Bowen, W.C.; Tseng, G.C.; Luo, J.H.; Orr, A.; Michalopoulos, G.K. RNA interference against hepatic epidermal growth factor receptor has suppressive effects on liver regeneration in rats. Am. J. Pathol. 2010, 176, 2669-2681. [CrossRef] [PubMed]

65. Van Buren, G., 2nd; Yang, A.D.; Dallas, N.A.; Gray, M.J.; Lim, S.J.; Xia, L.; Fan, F.; Somcio, R.; Wu, Y.; Hicklin, D.J.; et al. Effect of molecular therapeutics on liver regeneration in a murine model. J. Clin. Oncol. 2008, 26, 1836-1842. [CrossRef] [PubMed]

66. Zerrad-Saadi, A.; Lambert-Blot, M.; Mitchell, C.; Bretes, H.; Collin de l'Hortet, A.; Baud, V.; Chereau, F.; Sotiropoulos, A.; Kopchick, J.J.; Liao, L.; et al. GH receptor plays a major role in liver regeneration through the control of EGFR and ERK1/2 activation. Endocrinology 2011, 152, 2731-2741. [CrossRef] [PubMed]

67. Collin de l'Hortet, A.; Zerrad-Saadi, A.; Prip-Buus, C.; Fauveau, V.; Helmy, N.; Ziol, M.; Vons, C.; Billot, K.; Baud, V.; Gilgenkrantz, H.; et al. GH administration rescues fatty liver regeneration impairment by restoring GH/EGFR pathway deficiency. Endocrinology 2014, 155, 2545-2554. [CrossRef] [PubMed]

68. Tan, X.; Behari, J.; Cieply, B.; Michalopoulos, G.K.; Monga, S.P. Conditional deletion of $\beta$-catenin reveals its role in liver growth and regeneration. Gastroenterology 2006, 131, 1561-1572. [CrossRef] [PubMed]

69. Zhou, B.; Fan, Y.; Rao, J.; Xu, Z.; Liu, Y.; Lu, L.; Li, G. Matrix Metalloproteinases-9 deficiency impairs liver regeneration through epidermal growth factor receptor signaling in partial hepatectomy mice. J. Surg. Res. 2015, 197, 201-209. [CrossRef] [PubMed]

70. Berasain, C.; Garcia-Trevijano, E.R.; Castillo, J.; Erroba, E.; Santamaria, M.; Lee, D.C.; Prieto, J.; Avila, M.A. Novel role for amphiregulin in protection from liver injury. J. Biol. Chem. 2005, 280, 19012-19020. [CrossRef] [PubMed]

71. Pardo-Saganta, A.; Latasa, M.U.; Castillo, J.; Alvarez-Asiain, L.; Perugorria, M.J.; Sarobe, P.; Rodriguez-Ortigosa, C.M.; Prieto, J.; Berasain, C.; Santamaria, M.; et al. The epidermal growth factor receptor ligand amphiregulin is a negative regulator of hepatic acute-phase gene expression. J. Hepatol. 2009, 51, 1010-1020. [CrossRef] [PubMed]

72. Kanda, D.; Takagi, H.; Toyoda, M.; Horiguchi, N.; Nakajima, H.; Otsuka, T.; Mori, M. Transforming growth factor $\alpha$ protects against Fas-mediated liver apoptosis in mice. FEBS Lett. 2002, 519, 11-15. [CrossRef]

73. Khai, N.C.; Takahashi, T.; Ushikoshi, H.; Nagano, S.; Yuge, K.; Esaki, M.; Kawai, T.; Goto, K.; Murofushi, Y.; Fujiwara, T.; et al. In vivo hepatic HB-EGF gene transduction inhibits Fas-induced liver injury and induces liver regeneration in mice: A comparative study to HGF. J. Hepatol. 2006, 44, 1046-1054. [CrossRef] [PubMed]

74. Murthy, A.; Defamie, V.; Smookler, D.S.; di Grappa, M.A.; Horiuchi, K.; Federici, M.; Sibilia, M.; Blobel, C.P.; Khokha, R. Ectodomain shedding of EGFR ligands and TNFR1 dictates hepatocyte apoptosis during fulminant hepatitis in mice. J. Clin. Investig. 2010, 120, 2731-2744. [CrossRef] [PubMed]

75. Li, G.; Han, C.; Xu, L.; Lim, K.; Isse, K.; Wu, T. Cyclooxygenase-2 prevents Fas-induced liver injury through up-regulation of epidermal growth factor receptor. Hepatology 2009, 50, 834-843. [CrossRef] [PubMed]

76. Lanaya, H.; Natarajan, A.; Komposch, K.; Li, L.; Amberg, N.; Chen, L.; Wculek, S.K.; Hammer, M.; Zenz, R.; Peck-Radosavljevic, M.; et al. EGFR has a tumour-promoting role in liver macrophages during hepatocellular carcinoma formation. Nat. Cell Biol. 2014, 16, 972-981, 971-977. [CrossRef] [PubMed]

77. Vuppalanchi, R.; Chalasani, N. Nonalcoholic fatty liver disease and nonalcoholic steatohepatitis: Selected practical issues in their evaluation and management. Hepatology 2009, 49, 306-317. [CrossRef] [PubMed] 
78. Louvet, A.; Mathurin, P. Alcoholic liver disease: Mechanisms of injury and targeted treatment. Nat. Rev. Gastroenterol. Hepatol. 2015, 12, 231-242. [CrossRef] [PubMed]

79. Bataller, R.; Brenner, D.A. Liver fibrosis. J. Clin. Investig. 2005, 115, 209-218. [CrossRef] [PubMed]

80. Fujii, T.; Fuchs, B.C.; Yamada, S.; Lauwers, G.Y.; Kulu, Y.; Goodwin, J.M.; Lanuti, M.; Tanabe, K.K. Mouse model of carbon tetrachloride induced liver fibrosis: Histopathological changes and expression of CD133 and epidermal growth factor. BMC Gastroenterol. 2010, 10. [CrossRef] [PubMed]

81. Kiso, S.; Kawata, S.; Tamura, S.; Ito, N.; Tsushima, H.; Yamada, A.; Higashiyama, S.; Taniguchi, N.; Matsuzawa, Y. Expression of heparin-binding EGF-like growth factor in rat liver injured by carbon tetrachloride or D-galactosamine. Biochem. Biophys. Res. Commun. 1996, 220, 285-288. [CrossRef] [PubMed]

82. Kiso, S.; Kawata, S.; Tamura, S.; Miyagawa, J.; Ito, N.; Tsushima, H.; Yamada, A.; Umeki, S.; Higashiyama, S.; Taniguchi, N.; et al. Expression of heparin-binding epidermal growth factor-like growth factor in the hepatocytes of fibrotic rat liver during hepatocarcinogenesis. J. Gastroenterol. Hepatol. 1999, 14, 1203-1209. [CrossRef] [PubMed]

83. Dalu, A.; Cronin, G.M.; Lyn-Cook, B.D.; Mehendale, H.M. Age-related differences in TGF- $\alpha$ and proto-oncogenes expression in rat liver after a low dose of carbon tetrachloride. J. Biochem. Toxicol. 1995, 10, 259-264. [CrossRef] [PubMed]

84. Perugorria, M.J.; Latasa, M.U.; Nicou, A.; Cartagena-Lirola, H.; Castillo, J.; Goni, S.; Vespasiani-Gentilucci, U.; Zagami, M.G.; Lotersztajn, S.; Prieto, J.; et al. The epidermal growth factor receptor ligand amphiregulin participates in the development of mouse liver fibrosis. Hepatology 2008, 48, 1251-1261. [CrossRef] [PubMed]

85. Takemura, T.; Yoshida, Y.; Kiso, S.; Saji, Y.; Ezaki, H.; Hamano, M.; Kizu, T.; Egawa, M.; Chatani, N.; Furuta, K.; et al. Conditional knockout of heparin-binding epidermal growth factor-like growth factor in the liver accelerates carbon tetrachloride-induced liver injury in mice. Hepatol. Res. 2013, 43, 384-393. [CrossRef] [PubMed]

86. Huang, G.; Besner, G.E.; Brigstock, D.R. Heparin-binding epidermal growth factor-like growth factor suppresses experimental liver fibrosis in mice. Lab. Investig. 2012, 92, 703-712. [CrossRef] [PubMed]

87. Zhang, D.; Zhang, J.; Jiang, X.; Li, X.; Wang, Y.; Ma, J.; Jiang, H. Heparin-binding epidermal growth factor-like growth factor: A hepatic stellate cell proliferation inducer via ErbB receptors. J. Gastroenterol. Hepatol. 2014, 29, 623-632. [CrossRef] [PubMed]

88. Wu, B.; Wang, C.W.; Xu, J.R.; Zhu, J.Q. Effect of epidermal growth factor on cultured rat hepatocytes poisoned by $\mathrm{CCl}_{4}$. Zhongguo Yao Li Xue Bao 1997, 18, 176-179. [PubMed]

89. Berlanga, J.; Caballero, M.E.; Ramirez, D.; Torres, A.; Valenzuela, C.; Lodos, J.; Playford, R.J. Epidermal growth factor protects against carbon tetrachloride-induced hepatic injury. Clin. Sci. (Lond.) 1998, 94, 219-223. [CrossRef] [PubMed]

90. El Taghdouini, A.; Najimi, M.; Sancho-Bru, P.; Sokal, E.; van Grunsven, L.A. In vitro reversion of activated primary human hepatic stellate cells. Fibrogenes. Tissue Repair 2015, 8. [CrossRef] [PubMed]

91. Fuchs, B.C.; Hoshida, Y.; Fujii, T.; Wei, L.; Yamada, S.; Lauwers, G.Y.; McGinn, C.M.; DePeralta, D.K.; Chen, X.; Kuroda, T.; et al. Epidermal growth factor receptor inhibition attenuates liver fibrosis and development of hepatocellular carcinoma. Hepatology 2014, 59, 1577-1590. [CrossRef] [PubMed]

92. Berasain, C.; Perugorria, M.J.; Latasa, M.U.; Castillo, J.; Goni, S.; Santamaria, M.; Prieto, J.; Avila, M.A. The epidermal growth factor receptor: A link between inflammation and liver cancer. Exp. Biol. Med. (Maywood) 2009, 234, 713-725. [CrossRef] [PubMed]

93. Arabpour, M.; Poelstra, K.; Helfrich, W.; Bremer, E.; Haisma, H.J. Targeted elimination of activated hepatic stellate cells by an anti-epidermal growth factor-receptor single chain fragment variable antibody-tumor necrosis factor-related apoptosis-inducing ligand (scFv425-sTRAIL). J. Gene Med. 2014, 16, 281-290. [CrossRef] [PubMed]

94. Wang, L.P.; Dong, J.Z.; Xiong, L.J.; Shi, K.Q.; Zou, Z.L.; Zhang, S.N.; Cao, S.T.; Lin, Z.; Chen, Y.P. BMP-7 attenuates liver fibrosis via regulation of epidermal growth factor receptor. Int. J. Clin. Exp. Pathol. 2014, 7, 3537-3547. [PubMed]

95. Svegliati-Baroni, G.; Ridolfi, F.; Hannivoort, R.; Saccomanno, S.; Homan, M.; de Minicis, S.; Jansen, P.L.; Candelaresi, C.; Benedetti, A.; Moshage, H. Bile acids induce hepatic stellate cell proliferation via activation of the epidermal growth factor receptor. Gastroenterology 2005, 128, 1042-1055. [CrossRef] [PubMed] 
96. Sommerfeld, A.; Reinehr, R.; Haussinger, D. Bile acid-induced epidermal growth factor receptor activation in quiescent rat hepatic stellate cells can trigger both proliferation and apoptosis. J. Biol. Chem. 2009, 284, 22173-22183. [CrossRef] [PubMed]

97. Oikawa, H.; Maesawa, C.; Tatemichi, Y.; Nishinari, Y.; Nishiya, M.; Mizugai, H.; Ikeda, A.; Oikawa, K.; Takikawa, Y.; Masuda, T. A disintegrin and metalloproteinase 17 (ADAM17) mediates epidermal growth factor receptor transactivation by angiotensin ii on hepatic stellate cells. Life Sci. 2014, 97, 137-144. [CrossRef] [PubMed]

98. Takemura, T.; Yoshida, Y.; Kiso, S.; Kizu, T.; Furuta, K.; Ezaki, H.; Hamano, M.; Egawa, M.; Chatani, N.; Kamada, Y.; et al. Conditional loss of heparin-binding EGF-like growth factor results in enhanced liver fibrosis after bile duct ligation in mice. Biochem. Biophys. Res. Commun. 2013, 437, 185-191. [CrossRef] [PubMed]

99. Tomita, K.; Haga, H.; Mizuno, K.; Katsumi, T.; Sato, C.; Okumoto, K.; Nishise, Y.; Watanabe, H.; Saito, T.; Ueno, Y. Epiregulin promotes the emergence and proliferation of adult liver progenitor cells. Am. J. Physiol. Gastrointest. Liver Physiol. 2014, 307, G50-G57. [CrossRef] [PubMed]

100. McKee, C.; Sigala, B.; Soeda, J.; Mouralidarane, A.; Morgan, M.; Mazzoccoli, G.; Rappa, F.; Cappello, F.; Cabibi, D.; Pazienza, V.; et al. Amphiregulin activates human hepatic stellate cells and is upregulated in non alcoholic steatohepatitis. Sci. Rep. 2015, 5. [CrossRef] [PubMed]

101. Ohyama, T.; Yamazaki, Y.; Sato, K.; Horiguchi, N.; Ichikawa, T.; Kakizaki, S.; Takagi, H.; Mori, M. Transforming growth factor- $\alpha$ attenuates hepatic fibrosis: Possible involvement of matrix metalloproteinase-1. Liver Int. 2011, 31, 572-584. [CrossRef] [PubMed]

102. Kato, J.; Sato, Y.; Inui, N.; Nakano, Y.; Takimoto, R.; Takada, K.; Kobune, M.; Kuroiwa, G.; Miyake, S.; Kohgo, Y.; et al. Ethanol induces transforming growth factor- $\alpha$ expression in hepatocytes, leading to stimulation of collagen synthesis by hepatic stellate cells. Alcohol. Clin. Exp. Res. 2003, 27, 58S-63S. [CrossRef] [PubMed]

103. Deaciuc, I.V.; D’Souza, N.B.; Burikhanov, R.; Lee, E.Y.; Tarba, C.N.; McClain, C.J.; de Villiers, W.J. Epidermal growth factor protects the liver against alcohol-induced injury and sensitization to bacterial lipopolysaccharide. Alcohol. Clin. Exp. Res. 2002, 26, 864-874. [CrossRef] [PubMed]

104. Torre, L.A.; Bray, F.; Siegel, R.L.; Ferlay, J.; Lortet-Tieulent, J.; Jemal, A. Global cancer statistics, 2012. CA Cancer J. Clin. 2015, 65, 87-108. [CrossRef] [PubMed]

105. Mittal, S.; El-Serag, H.B. Epidemiology of hepatocellular carcinoma: Consider the population. J. Clin. Gastroenterol. 2013, 47 (Suppl.), S2-S6. [CrossRef] [PubMed]

106. El-Serag, H.B. Hepatocellular carcinoma. N. Engl. J. Med. 2011, 365, 1118-1127. [CrossRef] [PubMed]

107. De Martel, C.; Ferlay, J.; Franceschi, S.; Vignat, J.; Bray, F.; Forman, D.; Plummer, M. Global burden of cancers attributable to infections in 2008: A review and synthetic analysis. Lancet Oncol. 2012, 13, 607-615. [CrossRef]

108. Farazi, P.A.; DePinho, R.A. Hepatocellular carcinoma pathogenesis: From genes to environment. Nat. Rev. Cancer 2006, 6, 674-687. [CrossRef] [PubMed]

109. Qiao, Q.; Zhang, J.; Wang, W.; Li, Q. Over expression of transforming growth factor- $\alpha$ and epidermal growth factor receptor in human hepatic cirrhosis tissues. Hepatogastroenterology 2008, 55, 169-172. [PubMed]

110. Harada, K.; Shiota, G.; Kawasaki, H. Transforming growth factor- $\alpha$ and epidermal growth factor receptor in chronic liver disease and hepatocellular carcinoma. Liver 1999, 19, 318-325. [CrossRef] [PubMed]

111. Kira, S.; Nakanishi, T.; Suemori, S.; Kitamoto, M.; Watanabe, Y.; Kajiyama, G. Expression of transforming growth factor $\alpha$ and epidermal growth factor receptor in human hepatocellular carcinoma. Liver 1997, 17, 177-182. [CrossRef] [PubMed]

112. Ito, Y.; Takeda, T.; Sakon, M.; Tsujimoto, M.; Higashiyama, S.; Noda, K.; Miyoshi, E.; Monden, M.; Matsuura, N. Expression and clinical significance of ErbB receptor family in hepatocellular carcinoma. Br. J. Cancer 2001, 84, 1377-1383. [CrossRef] [PubMed]

113. Daveau, M.; Scotte, M.; Francois, A.; Coulouarn, C.; Ros, G.; Tallet, Y.; Hiron, M.; Hellot, M.F.; Salier, J.P. Hepatocyte growth factor, transforming growth factor $\alpha$, and their receptors as combined markers of prognosis in hepatocellular carcinoma. Mol. Carcinogenes. 2003, 36, 130-141. [CrossRef] [PubMed]

114. Chung, Y.H.; Kim, J.A.; Song, B.C.; Lee, G.C.; Koh, M.S.; Lee, Y.S.; Lee, S.G.; Suh, D.J. Expression of transforming growth factor- $\alpha$ mRNA in livers of patients with chronic viral hepatitis and hepatocellular carcinoma. Cancer 2000, 89, 977-982. [CrossRef] 
115. Moon, W.S.; Park, H.S.; Yu, K.H.; Park, M.Y.; Kim, K.R.; Jang, K.Y.; Kim, J.S.; Cho, B.H. Expression of $\beta$ cellulin and epidermal growth factor receptor in hepatocellular carcinoma: Implications for angiogenesis. Hum. Pathol. 2006, 37, 1324-1332. [CrossRef] [PubMed]

116. Inui, Y.; Higashiyama, S.; Kawata, S.; Tamura, S.; Miyagawa, J.; Taniguchi, N.; Matsuzawa, Y. Expression of heparin-binding epidermal growth factor in human hepatocellular carcinoma. Gastroenterology 1994, 107, 1799-1804. [PubMed]

117. Castillo, J.; Erroba, E.; Perugorria, M.J.; Santamaria, M.; Lee, D.C.; Prieto, J.; Avila, M.A.; Berasain, C. Amphiregulin contributes to the transformed phenotype of human hepatocellular carcinoma cells. Cancer Res. 2006, 66, 6129-6138. [CrossRef] [PubMed]

118. Buckley, A.F.; Burgart, L.J.; Sahai, V.; Kakar, S. Epidermal growth factor receptor expression and gene copy number in conventional hepatocellular carcinoma. Am. J. Clin. Pathol. 2008, 129, 245-251. [CrossRef] [PubMed]

119. Abu Dayyeh, B.K.; Yang, M.; Fuchs, B.C.; Karl, D.L.; Yamada, S.; Sninsky, J.J.; O’Brien, T.R.; Dienstag, J.L.; Tanabe, K.K.; Chung, R.T. A functional polymorphism in the epidermal growth factor gene is associated with risk for hepatocellular carcinoma. Gastroenterology 2011, 141, 141-149. [CrossRef] [PubMed]

120. Tanabe, K.K.; Lemoine, A.; Finkelstein, D.M.; Kawasaki, H.; Fujii, T.; Chung, R.T.; Lauwers, G.Y.; Kulu, Y.; Muzikansky, A.; Kuruppu, D.; et al. Epidermal growth factor gene functional polymorphism and the risk of hepatocellular carcinoma in patients with cirrhosis. JAMA 2008, 299, 53-60. [CrossRef] [PubMed]

121. Keng, V.W.; Sia, D.; Sarver, A.L.; Tschida, B.R.; Fan, D.; Alsinet, C.; Sole, M.; Lee, W.L.; Kuka, T.P.; Moriarity, B.S.; et al. Sex bias occurrence of hepatocellular carcinoma in poly7 molecular subclass is associated with EGFR. Hepatology 2013, 57, 120-130. [CrossRef] [PubMed]

122. Su, Q.; Liu, Y. Expression of c-ErbB-2 protein and EGF receptor in hepatitis b, cirrhosis and hepatocellular carcinoma. Zhonghua Bing Li Xue Za Zhi Chin. J. Pathol. 1995, 24, 93-95.

123. Kew, M.C. Hepatitis B virus x protein in the pathogenesis of hepatitis B virus-induced hepatocellular carcinoma. J. Gastroenterol. Hepatol. 2011, 26 (Suppl. 1), 144-152. [CrossRef] [PubMed]

124. Menzo, S.; Clementi, M.; Alfani, E.; Bagnarelli, P.; Iacovacci, S.; Manzin, A.; Dandri, M.; Natoli, G.; Levrero, M.; Carloni, G. Trans-activation of epidermal growth factor receptor gene by the hepatitis B virus $x$-gene product. Virology 1993, 196, 878-882. [CrossRef] [PubMed]

125. Miyaki, M.; Sato, C.; Sakai, K.; Konishi, M.; Tanaka, K.; Muraoka, M.; Kikuchi-Yanoshita, R.; Nadaoka, Y.; Kanda, H.; Kitagawa, T. Malignant transformation and EGFR activation of immortalized mouse liver epithelial cells caused by HBV enhancer-X from a human hepatocellular carcinoma. Int. J. Cancer 2000, 85, 518-522. [CrossRef]

126. Zhu, H.; Wang, Y.; Chen, J.; Cheng, G.; Xue, J. Transgenic mice expressing hepatitis B virus $x$ protein are more susceptible to carcinogen induced hepatocarcinogenesis. Exp. Mol. Pathol. 2004, 76, 44-50. [CrossRef] [PubMed]

127. Chen, Y.J.; Chien, P.H.; Chen, W.S.; Chien, Y.F.; Hsu, Y.Y.; Wang, L.Y.; Chen, J.Y.; Lin, C.W.; Huang, T.C.; $\mathrm{Yu}$, Y.L.; et al. Hepatitis B virus-encoded $\mathrm{x}$ protein downregulates EGFR expression via inducing microRNA-7 in hepatocellular carcinoma cells. Evid. Based Complement. Altern. Med. 2013, 2013, 682380. [CrossRef] [PubMed]

128. Zhang, J.; Wang, W.L.; Li, Q.; Qiao, Q. Expression of transforming growth factor- $\alpha$ and hepatitis B surface antigen in human hepatocellular carcinoma tissues and its significance. World J. Gastroenterol. 2004, 10, 830-833. [PubMed]

129. Dai, K.; Huang, L.; Chen, J.; Yang, L.; Gong, Z. Amphiregulin promotes the immunosuppressive activity of intrahepatic $\mathrm{CD} 4^{+}$regulatory $\mathrm{T}$ cells to impair $\mathrm{CD} 8^{+} \mathrm{T}$ cell immunity against hepatitis $\mathrm{B}$ virus infection. Immunology 2014, 144, 506-517. [CrossRef] [PubMed]

130. Badawy, A.A.; El-Hindawi, A.; Hammam, O.; Moussa, M.; Gabal, S.; Said, N. Impact of epidermal growth factor receptor and transforming growth factor- $\alpha$ on hepatitis $\mathrm{C}$ virus-induced hepatocarcinogenesis. APMIS 2015, 123, 823-831. [CrossRef] [PubMed]

131. Shehata, F.; Abdel Monem, N.; Sakr, M.; Kasem, S.; Balbaa, M. Epidermal growth factor, its receptor and transforming growth factor- $\beta 1$ in the diagnosis of HCV-induced hepatocellular carcinoma. Med. Oncol. 2013, 30, 673. [CrossRef] [PubMed] 
132. Divella, R.; Daniele, A.; Gadaleta, C.; Tufaro, A.; Venneri, M.T.; Paradiso, A.; Quaranta, M. Circulating transforming growth factor- $\beta$ and epidermal growth factor receptor as related to virus infection in liver carcinogenesis. Anticancer Res. 2012, 32, 141-145. [PubMed]

133. Pei, R.; Chen, H.; Lu, L.; Zhu, W.; Beckebaum, S.; Cicinnati, V.; Lu, M.; Chen, X. Hepatitis c virus infection induces the expression of amphiregulin, a factor related to the activation of cellular survival pathways and required for efficient viral assembly. J. Gen. Virol. 2011, 92, 2237-2248. [CrossRef] [PubMed]

134. Moriya, K.; Fujie, H.; Shintani, Y.; Yotsuyanagi, H.; Tsutsumi, T.; Ishibashi, K.; Matsuura, Y.; Kimura, S.; Miyamura, T.; Koike, K. The core protein of hepatitis c virus induces hepatocellular carcinoma in transgenic mice. Nat. Med. 1998, 4, 1065-1067. [CrossRef] [PubMed]

135. Sato, Y.; Kato, J.; Takimoto, R.; Takada, K.; Kawano, Y.; Miyanishi, K.; Kobune, M.; Sato, Y.; Takayama, T.; Matunaga, T.; et al. Hepatitis c virus core protein promotes proliferation of human hepatoma cells through enhancement of transforming growth factor $\alpha$ expression via activation of nuclear factor- $\mathrm{kB}$. Gut 2006, 55, 1801-1808. [CrossRef] [PubMed]

136. Diao, J.; Pantua, H.; Ngu, H.; Komuves, L.; Diehl, L.; Schaefer, G.; Kapadia, S.B. Hepatitis C virus induces epidermal growth factor receptor activation via CD81 binding for viral internalization and entry. J. Virol. 2012, 86, 10935-10949. [CrossRef] [PubMed]

137. Lupberger, J.; Zeisel, M.B.; Xiao, F.; Thumann, C.; Fofana, I.; Zona, L.; Davis, C.; Mee, C.J.; Turek, M.; Gorke, S.; et al. EGFR and EphA2 are host factors for hepatitis $C$ virus entry and possible targets for antiviral therapy. Nat. Med. 2011, 17, 589-595. [CrossRef] [PubMed]

138. Zona, L.; Lupberger, J.; Sidahmed-Adrar, N.; Thumann, C.; Harris, H.J.; Barnes, A.; Florentin, J.; Tawar, R.G.; Xiao, F.; Turek, M.; et al. HRAs signal transduction promotes hepatitis $C$ virus cell entry by triggering assembly of the host tetraspanin receptor complex. Cell Host Microbe 2013, 13, 302-313. [CrossRef] [PubMed]

139. Kim, S.; Ishida, H.; Yamane, D.; Yi, M.; Swinney, D.C.; Foung, S.; Lemon, S.M. Contrasting roles of mitogen-activated protein kinases in cellular entry and replication of hepatitis c virus: Mknk1 facilitates cell entry. J. Virol. 2013, 87, 4214-4224. [CrossRef] [PubMed]

140. Mankouri, J.; Griffin, S.; Harris, M. The hepatitis c virus non-structural protein NS5A alters the trafficking profile of the epidermal growth factor receptor. Traffic 2008, 9, 1497-1509. [CrossRef] [PubMed]

141. Igloi, Z.; Kazlauskas, A.; Saksela, K.; Macdonald, A.; Mankouri, J.; Harris, M. Hepatitis c virus NS5A protein blocks epidermal growth factor receptor degradation via a proline motif-dependent interaction. J. Gen. Virol. 2015, 96, 2133-2144. [CrossRef] [PubMed]

142. Patton, J.B.; George, D.; Chang, K.O. Bile acids promote HCV replication through the EGFR/ERK pathway in replicon-harboring cells. Intervirology 2011, 54, 339-348. [CrossRef] [PubMed]

143. Meyer, K.; Kwon, Y.C.; Liu, S.; Hagedorn, C.H.; Ray, R.B.; Ray, R. Interferon- $\alpha$ inducible protein 6 impairs EGFR activation by CD81 and inhibits hepatitis c virus infection. Sci. Rep. 2015, 5. [CrossRef] [PubMed]

144. Lupberger, J.; Duong, F.H.; Fofana, I.; Zona, L.; Xiao, F.; Thumann, C.; Durand, S.C.; Pessaux, P.; Zeisel, M.B.; Heim, M.H.; et al. Epidermal growth factor receptor signaling impairs the antiviral activity of interferon- $\alpha$. Hepatology 2013, 58, 1225-1235. [CrossRef] [PubMed]

145. Wong, R.W.; Kwan, R.W.; Mak, P.H.; Mak, K.K.; Sham, M.H.; Chan, S.Y. Overexpression of epidermal growth factor induced hypospermatogenesis in transgenic mice. J. Biol. Chem. 2000, 275, 18297-18301. [CrossRef] [PubMed]

146. Chan, S.Y.; Wong, R.W. Expression of epidermal growth factor in transgenic mice causes growth retardation. J. Biol. Chem. 2000, 275, 38693-38698. [CrossRef] [PubMed]

147. Jhappan, C.; Stahle, C.; Harkins, R.N.; Fausto, N.; Smith, G.H.; Merlino, G.T. TGF $\alpha$ overexpression in transgenic mice induces liver neoplasia and abnormal development of the mammary gland and pancreas. Cell 1990, 61, 1137-1146. [CrossRef]

148. Sandgren, E.P.; Luetteke, N.C.; Palmiter, R.D.; Brinster, R.L.; Lee, D.C. Overexpression of TGF $\alpha$ in transgenic mice: Induction of epithelial hyperplasia, pancreatic metaplasia, and carcinoma of the breast. Cell 1990, 61, 1121-1135. [CrossRef]

149. Cook, P.W.; Piepkorn, M.; Clegg, C.H.; Plowman, G.D.; DeMay, J.M.; Brown, J.R.; Pittelkow, M.R. Transgenic expression of the human amphiregulin gene induces a psoriasis-like phenotype. J. Clin. Investig. 1997, 100, 2286-2294. [CrossRef] [PubMed] 
150. Schneider, M.R.; Dahlhoff, M.; Herbach, N.; Renner-Mueller, I.; Dalke, C.; Puk, O.; Graw, J.; Wanke, R.; Wolf, E. Bcellulin overexpression in transgenic mice causes disproportionate growth, pulmonary hemorrhage syndrome, and complex eye pathology. Endocrinology 2005, 146, 5237-5246. [CrossRef] [PubMed]

151. Provenzano, A.P.; Besner, G.E.; James, P.F.; Harding, P.A. Heparin-binding EGF-like growth factor (HB-EGF) overexpression in transgenic mice downregulates insulin-like growth factor binding protein (IGFBP)-3 and -4 mRNA. Growth Factors 2005, 23, 19-31. [CrossRef] [PubMed]

152. Dahlhoff, M.; Muller, A.K.; Wolf, E.; Werner, S.; Schneider, M.R. Epigen transgenic mice develop enlarged sebaceous glands. J. Investig. Dermatol. 2010, 130, 623-626. [CrossRef] [PubMed]

153. Webber, E.M.; Wu, J.C.; Wang, L.; Merlino, G.; Fausto, N. Overexpression of transforming growth factor- $\alpha$ causes liver enlargement and increased hepatocyte proliferation in transgenic mice. Am. J. Pathol. 1994, 145, 398-408. [PubMed]

154. Pires, P.W.; Furtado, K.S.; Justullin, L.A., Jr.; Rodrigues, M.A.; Felisbino, S.L.; Barbisan, L.F. Chronic ethanol intake promotes double gluthatione $S$-transferase/transforming growth factor- $\alpha$-positive hepatocellular lesions in male wistar rats. Cancer Sci. 2008, 99, 221-228. [CrossRef] [PubMed]

155. Thorgeirsson, S.S.; Santoni-Rugiu, E. Transgenic mouse models in carcinogenesis: Interaction of c-myc with transforming growth factor $\alpha$ and hepatocyte growth factor in hepatocarcinogenesis. Br. J. Clin. Pharmacol. 1996, 42, 43-52. [CrossRef] [PubMed]

156. Thorgeirsson, S.S.; Santoni-Rugiu, E.; Davis, C.D.; Snyderwine, E.G. Hepatic tumor induction in c-myc mono-transgenic and TGF- $\alpha$ /c-myc double-transgenic mice. Arch. Toxicol. Suppl. 1997, 19, 359-366. [PubMed]

157. Komuves, L.G.; Feren, A.; Jones, A.L.; Fodor, E. Expression of epidermal growth factor and its receptor in cirrhotic liver disease. J. Histochem. Cytochem. 2000, 48, 821-830. [CrossRef] [PubMed]

158. Borlak, J.; Meier, T.; Halter, R.; Spanel, R.; Spanel-Borowski, K. Epidermal growth factor-induced hepatocellular carcinoma: Gene expression profiles in precursor lesions, early stage and solitary tumours. Oncogene 2005, 24, 1809-1819. [CrossRef] [PubMed]

159. Hoshida, Y.; Villanueva, A.; Kobayashi, M.; Peix, J.; Chiang, D.Y.; Camargo, A.; Gupta, S.; Moore, J.; Wrobel, M.J.; Lerner, J.; et al. Gene expression in fixed tissues and outcome in hepatocellular carcinoma. N. Engl. J. Med. 2008, 359, 1995-2004. [CrossRef] [PubMed]

160. Sagmeister, S.; Drucker, C.; Losert, A.; Grusch, M.; Daryabeigi, A.; Parzefall, W.; Rohr-Udilova, N.; Bichler, C.; Smedsrod, B.; Kandioler, D.; et al. HB-EGF is a paracrine growth stimulator for early tumor prestages in inflammation-associated hepatocarcinogenesis. J. Hepatol. 2008, 49, 955-964. [CrossRef] [PubMed]

161. Berasain, C.; Nicou, A.; Garcia-Irigoyen, O.; Latasa, M.U.; Urtasun, R.; Elizalde, M.; Salis, F.; Perugorria, M.J.; Prieto, J.; Recio, J.A.; et al. Epidermal growth factor receptor signaling in hepatocellular carcinoma: Inflammatory activation and a new intracellular regulatory mechanism. Dig. Dis. 2012, 30, 524-531. [CrossRef] [PubMed]

162. Latasa, M.U.; Salis, F.; Urtasun, R.; Garcia-Irigoyen, O.; Elizalde, M.; Uriarte, I.; Santamaria, M.; Feo, F.; Pascale, R.M.; Prieto, J.; et al. Regulation of amphiregulin gene expression by $\beta$-catenin signaling in human hepatocellular carcinoma cells: A novel crosstalk between FGF19 and the EGFR system. PLoS ONE 2012, 7, e52711. [CrossRef] [PubMed]

163. Urtasun, R.; Latasa, M.U.; Demartis, M.I.; Balzani, S.; Goni, S.; Garcia-Irigoyen, O.; Elizalde, M.; Azcona, M.; Pascale, R.M.; Feo, F.; et al. Connective tissue growth factor autocriny in human hepatocellular carcinoma: Oncogenic role and regulation by epidermal growth factor receptor/yes-associated protein-mediated activation. Hepatology 2011, 54, 2149-2158. [CrossRef] [PubMed]

164. Mazzocca, A.; Fransvea, E.; Dituri, F.; Lupo, L.; Antonaci, S.; Giannelli, G. Down-regulation of connective tissue growth factor by inhibition of transforming growth factor $\beta$ blocks the tumor-stroma cross-talk and tumor progression in hepatocellular carcinoma. Hepatology 2010, 51, 523-534. [CrossRef] [PubMed]

165. Sancho, P.; Fabregat, I. NADPH oxidase nox1 controls autocrine growth of liver tumor cells through up-regulation of the epidermal growth factor receptor pathway. J. Biol. Chem. 2010, 285, 24815-24824. [CrossRef] [PubMed]

166. Weinstein, I.B.; Joe, A.K. Mechanisms of disease: Oncogene addiction-A rationale for molecular targeting in cancer therapy. Nat. Clin. Pract. Oncol. 2006, 3, 448-457. [CrossRef] [PubMed]

167. Schafer, B.; Gschwind, A.; Ullrich, A. Multiple G-protein-coupled receptor signals converge on the epidermal growth factor receptor to promote migration and invasion. Oncogene 2004, 23, 991-999. [CrossRef] [PubMed] 
168. Reschke, M.; Ferby, I.; Stepniak, E.; Seitzer, N.; Horst, D.; Wagner, E.F.; Ullrich, A. Mitogen-inducible gene-6 is a negative regulator of epidermal growth factor receptor signaling in hepatocytes and human hepatocellular carcinoma. Hepatology 2010, 51, 1383-1390. [CrossRef] [PubMed]

169. Wang, R.Y.; Chen, L.; Chen, H.Y.; Hu, L.; Li, L.; Sun, H.Y.; Jiang, F.; Zhao, J.; Liu, G.M.; Tang, J.; et al. Muc15 inhibits dimerization of EGFR and PI3K-Akt signaling and is associated with aggressive hepatocellular carcinomas in patients. Gastroenterology 2013, 145, 1436-1448, e1431-e1412. [CrossRef] [PubMed]

170. Naugler, W.E.; Sakurai, T.; Kim, S.; Maeda, S.; Kim, K.; Elsharkawy, A.M.; Karin, M. Gender disparity in liver cancer due to sex differences in myd88-dependent IL-6 production. Science 2007, 317, 121-124. [CrossRef] [PubMed]

171. Huether, A.; Hopfner, M.; Sutter, A.P.; Schuppan, D.; Scherubl, H. Erlotinib induces cell cycle arrest and apoptosis in hepatocellular cancer cells and enhances chemosensitivity towards cytostatics. J. Hepatol. 2005, 43, 661-669. [CrossRef] [PubMed]

172. Hopfner, M.; Sutter, A.P.; Huether, A.; Schuppan, D.; Zeitz, M.; Scherubl, H. Targeting the epidermal growth factor receptor by Gefitinib for treatment of hepatocellular carcinoma. J. Hepatol. 2004, 41, 1008-1016. [CrossRef] [PubMed]

173. Okano, J.; Matsumoto, K.; Nagahara, T.; Murawaki, Y. Gefitinib and the modulation of the signaling pathways downstream of epidermal growth factor receptor in human liver cancer cells. J. Gastroenterol. 2006, 41, 166-176. [CrossRef] [PubMed]

174. Huether, A.; Hopfner, M.; Sutter, A.P.; Baradari, V.; Schuppan, D.; Scherubl, H. Signaling pathways involved in the inhibition of epidermal growth factor receptor by erlotinib in hepatocellular cancer. World J. Gastroenterol. 2006, 12, 5160-5167. [PubMed]

175. Schiffer, E.; Housset, C.; Cacheux, W.; Wendum, D.; Desbois-Mouthon, C.; Rey, C.; Clergue, F.; Poupon, R.; Barbu, V.; Rosmorduc, O. Gefitinib, an EGFR inhibitor, prevents hepatocellular carcinoma development in the rat liver with cirrhosis. Hepatology 2005, 41, 307-314. [CrossRef] [PubMed]

176. Matsuo, M.; Sakurai, H.; Saiki, I. ZD1839, a selective epidermal growth factor receptor tyrosine kinase inhibitor, shows antimetastatic activity using a hepatocellular carcinoma model. Mol. Cancer Ther. 2003, 2, 557-561. [PubMed]

177. Zhu, B.D.; Yuan, S.J.; Zhao, Q.C.; Li, X.; Li, Y.; Lu, Q.Y. Antitumor effect of Gefitinib, an epidermal growth factor receptor tyrosine kinase inhibitor, combined with cytotoxic agent on murine hepatocellular carcinoma. World J. Gastroenterol. 2005, 11, 1382-1386. [CrossRef] [PubMed]

178. Ueda, S.; Basaki, Y.; Yoshie, M.; Ogawa, K.; Sakisaka, S.; Kuwano, M.; Ono, M. PTEN/Akt signaling through epidermal growth factor receptor is prerequisite for angiogenesis by hepatocellular carcinoma cells that is susceptible to inhibition by Gefitinib. Cancer Res. 2006, 66, 5346-5353. [CrossRef] [PubMed]

179. Ueno, Y.; Sakurai, H.; Matsuo, M.; Choo, M.K.; Koizumi, K.; Saiki, I. Selective inhibition of TNF- $\alpha$-induced activation of mitogen-activated protein kinases and metastatic activities by Gefitinib. Br. J. Cancer 2005, 92, 1690-1695. [CrossRef] [PubMed]

180. Baselga, J.; Arteaga, C.L. Critical update and emerging trends in epidermal growth factor receptor targeting in cancer. J. Clin. Oncol. 2005, 23, 2445-2459. [CrossRef] [PubMed]

181. Marshall, J. Clinical implications of the mechanism of epidermal growth factor receptor inhibitors. Cancer 2006, 107, 1207-1218. [CrossRef] [PubMed]

182. Giaccone, G. Targeting HER1/EGFR in cancer therapy: Experience with erlotinib. Future Oncol. 2005, 1, 449-460. [CrossRef] [PubMed]

183. O’Dwyer, P.J.; Giantonio, B.J.; Levy, D.E.; Kauh, J.S.; Fitzgerald, D.B.; Benson, A.B. Gefitinib in advanced unresectable hepatocellular carcinoma: Results from the Eastern Cooperative Oncology Group's Study E1203. J. Clin. Oncol. 2006, 24, $213 S$.

184. Llovet, J.M.; Bruix, J. Molecular targeted therapies in hepatocellular carcinoma. Hepatology 2008, 48, 1312-1327. [CrossRef] [PubMed]

185. Ramanathan, R.K.; Belani, C.P.; Singh, D.A.; Tanaka, M.; Lenz, H.J.; Yen, Y.; Kindler, H.L.; Iqbal, S.; Longmate, J.; Mack, P.C.; et al. A phase II study of lapatinib in patients with advanced biliary tree and hepatocellular cancer. Cancer Chemother. Pharmacol. 2009, 64, 777-783. [CrossRef] [PubMed]

186. Philip, P.A.; Mahoney, M.R.; Allmer, C.; Thomas, J.; Pitot, H.C.; Kim, G.; Donehower, R.C.; Fitch, T.; Picus, J.; Erlichman, C. Phase II study of erlotinib (OSI-774) in patients with advanced hepatocellular cancer. J. Clin. Oncol. 2005, 23, 6657-6663. [CrossRef] [PubMed] 
187. Thomas, M.B.; Chadha, R.; Glover, K.; Wang, X.; Morris, J.; Brown, T.; Rashid, A.; Dancey, J.; Abbruzzese, J.L. Phase 2 study of erlotinib in patients with unresectable hepatocellular carcinoma. Cancer 2007, 110, 1059-1067. [CrossRef] [PubMed]

188. Zhu, A.X.; Stuart, K.; Blaszkowsky, L.S.; Muzikansky, A.; Reitberg, D.P.; Clark, J.W.; Enzinger, P.C.; Bhargava, P.; Meyerhardt, J.A.; Horgan, K.; et al. Phase 2 study of cetuximab in patients with advanced hepatocellular carcinoma. Cancer 2007, 110, 581-589. [CrossRef] [PubMed]

189. Gruenwald, V.; Wilkens, L.; Gebel, M.; Greten, T.F.; Kubicka, S.; Ganser, A.; Manns, M.P.; Malek, N.P. A phase II open-label study of cetuximab in unresectable hepatocellular carcinoma: Final results. J. Clin. Oncol. 2007, 25,4598 .

190. Asnacios, A.; Fartoux, L.; Romano, O.; Tesmoingt, C.; Louafi, S.S.; Mansoubakht, T.; Artru, P.; Poynard, T.; Rosmorduc, O.; Hebbar, M.; et al. Gemcitabine plus oxaliplatin (GEMOX) combined with cetuximab in patients with progressive advanced stage hepatocellular carcinoma: Results of a multicenter phase 2 study. Cancer 2008, 112, 2733-2739. [CrossRef] [PubMed]

191. Hsu, C.H.; Kang, Y.K.; Yang, T.S.; Shun, C.T.; Shao, Y.Y.; Su, W.C.; Sandoval-Tan, J.; Chiou, T.J.; Jin, K.; Hsu, C.; et al. Bevacizumab with erlotinib as first-line therapy in asian patients with advanced hepatocellular carcinoma: A multicenter phase ii study. Oncology 2013, 85, 44-52. [CrossRef] [PubMed]

192. Philip, P.A.; Mahoney, M.R.; Holen, K.D.; Northfelt, D.W.; Pitot, H.C.; Picus, J.; Flynn, P.J.; Erlichman, C. Phase 2 study of bevacizumab plus erlotinib in patients with advanced hepatocellular cancer. Cancer 2012, 118, 2424-2430. [CrossRef] [PubMed]

193. Thomas, M.B.; Morris, J.S.; Chadha, R.; Iwasaki, M.; Kaur, H.; Lin, E.; Kaseb, A.; Glover, K.; Davila, M.; Abbruzzese, J. Phase II trial of the combination of bevacizumab and erlotinib in patients who have advanced hepatocellular carcinoma. J. Clin. Oncol. 2009, 27, 843-850. [CrossRef] [PubMed]

194. Blivet-Van Eggelpoel, M.J.; Chettouh, H.; Fartoux, L.; Aoudjehane, L.; Barbu, V.; Rey, C.; Priam, S.; Housset, C.; Rosmorduc, O.; Desbois-Mouthon, C. Epidermal growth factor receptor and HER-3 restrict cell response to sorafenib in hepatocellular carcinoma cells. J. Hepatol. 2012, 57, 108-115. [CrossRef] [PubMed]

195. Zhu, A.X.; Rosmorduc, O.; Evans, T.R.; Ross, P.J.; Santoro, A.; Carrilho, F.J.; Bruix, J.; Qin, S.; Thuluvath, P.J.; Llovet, J.M.; et al. Search: A phase iii, randomized, double-blind, placebo-controlled trial of sorafenib plus erlotinib in patients with advanced hepatocellular carcinoma. J. Clin. Oncol. 2015, 33, 559-566. [CrossRef] [PubMed]

196. Su, M.C.; Lien, H.C.; Jeng, Y.M. Absence of epidermal growth factor receptor exon 18-21 mutation in hepatocellular carcinoma. Cancer Lett. 2005, 224, 117-121. [CrossRef] [PubMed]

197. Lee, S.C.; Lim, S.G.; Soo, R.; Hsieh, W.S.; Guo, J.Y.; Putti, T.; Tao, Q.; Soong, R.; Goh, B.C. Lack of somatic mutations in EGFR tyrosine kinase domain in hepatocellular and nasopharyngeal carcinoma. Pharmacogenet. Genom. 2006, 16, 73-74. [CrossRef]

198. Fuchs, B.C.; Fujii, T.; Dorfman, J.D.; Goodwin, J.M.; Zhu, A.X.; Lanuti, M.; Tanabe, K.K. Epithelial-to-mesenchymal transition and integrin-linked kinase mediate sensitivity to epidermal growth factor receptor inhibition in human hepatoma cells. Cancer Res. 2008, 68, 2391-2399. [CrossRef] [PubMed]

199. Losert, A.; Lotsch, D.; Lackner, A.; Koppensteiner, H.; Peter-Vorosmarty, B.; Steiner, E.; Holzmann, K.; Grunt, T.; Schmid, K.; Marian, B.; et al. The major vault protein mediates resistance to epidermal growth factor receptor inhibition in human hepatoma cells. Cancer Lett. 2012, 319, 164-172. [CrossRef] [PubMed]

200. Desbois-Mouthon, C.; Baron, A.; Blivet-Van Eggelpoel, M.J.; Fartoux, L.; Venot, C.; Bladt, F.; Housset, C.; Rosmorduc, O. Insulin-like growth factor-1 receptor inhibition induces a resistance mechanism via the epidermal growth factor receptor/HER3/Akt signaling pathway: Rational basis for cotargeting insulin-like growth factor-1 receptor and epidermal growth factor receptor in hepatocellular carcinoma. Clin. Cancer Res. 2009, 15, 5445-5456. [PubMed]

201. Desbois-Mouthon, C.; Cacheux, W.; Blivet-Van Eggelpoel, M.J.; Barbu, V.; Fartoux, L.; Poupon, R.; Housset, C.; Rosmorduc, O. Impact of IGF-1R/EGFR cross-talks on hepatoma cell sensitivity to gefitinib. Int. J. Cancer 2006, 119, 2557-2566. [CrossRef] [PubMed]

202. Michalopoulos, G.K.; DeFrances, M.C. Liver regeneration. Science 1997, 276, 60-66. [CrossRef] [PubMed]

203. Scheving, L.A.; Stevenson, M.C.; Taylormoore, J.M.; Traxler, P.; Russell, W.E. Integral role of the EGF receptor in HGF-mediated hepatocyte proliferation. Biochem. Biophys. Res. Commun. 2002, 290, 197-203. [CrossRef] [PubMed] 
204. Gusenbauer, S.; Vlaicu, P.; Ullrich, A. HGF induces novel EGFR functions involved in resistance formation to tyrosine kinase inhibitors. Oncogene 2013, 32, 3846-3856. [CrossRef] [PubMed]

205. Ou, C.; Wu, F.X.; Luo, Y.; Cao, J.; Zhao, Y.N.; Yuan, W.P.; Li, Y.; Su, J.J. Expression and significance of epidermal growth factor receptor variant type III in hepatocellular carcinoma. Ai Zheng 2005, 24, 166-169. [PubMed]

206. Zhou, M.; Gong, B.; Gu, J.; Li, Z. EGFRVIII mRNA detection in the serum of patients with hepatocellular carcinoma. Liver Int. 2010, 30, 925-927. [CrossRef] [PubMed]

207. Wang, H.; Jiang, H.; Zhou, M.; Xu, Z.; Liu, S.; Shi, B.; Yao, X.; Yao, M.; Gu, J.; Li, Z. Epidermal growth factor receptor viii enhances tumorigenicity and resistance to 5-fluorouracil in human hepatocellular carcinoma. Cancer Lett. 2009, 279, 30-38. [CrossRef] [PubMed]

208. Jiang, H.; Wang, H.; Tan, Z.; Hu, S.; Wang, H.; Shi, B.; Yang, L.; Li, P.; Gu, J.; Wang, H.; et al. Growth suppression of human hepatocellular carcinoma xenografts by a monoclonal antibody ch12 directed to epidermal growth factor receptor variant iii. J. Biol. Chem. 2011, 286, 5913-5920. [CrossRef] [PubMed]

209. Jiang, H.; Dong, Q.; Luo, X.; Shi, B.; Wang, H.; Gao, H.; Kong, J.; Zhang, J.; Li, Z. The monoclonal antibody ch12 augments 5-fluorouracil-induced growth suppression of hepatocellular carcinoma xenografts expressing epidermal growth factor receptor variant iii. Cancer Lett. 2014, 342, 113-120. [CrossRef] [PubMed]

210. Yang, Y.; Jiang, H.; Gao, H.; Kong, J.; Zhang, P.; Hu, S.; Shi, B.; Zhang, P.; Yao, M.; Li, Z. The monoclonal antibody ch12 enhances the sorafenib-mediated growth inhibition of hepatocellular carcinoma xenografts expressing epidermal growth factor receptor variant iii. Neoplasia 2012, 14, 509-518. [CrossRef] [PubMed]

211. Alpini, G.; McGill, J.M.; Larusso, N.F. The pathobiology of biliary epithelia. Hepatology 2002, 35, $1256-1268$. [CrossRef] [PubMed]

212. Wehbe, H.; Henson, R.; Meng, F.; Mize-Berge, J.; Patel, T. Interleukin-6 contributes to growth in cholangiocarcinoma cells by aberrant promoter methylation and gene expression. Cancer Res. 2006, 66, 10517-10524. [CrossRef] [PubMed]

213. Ito, Y.; Takeda, T.; Sasaki, Y.; Sakon, M.; Yamada, T.; Ishiguro, S.; Imaoka, S.; Tsujimoto, M.; Higashiyama, S.; Monden, M.; et al. Expression and clinical significance of the ErbB family in intrahepatic cholangiocellular carcinoma. Pathol. Res. Pract. 2001, 197, 95-100. [CrossRef] [PubMed]

214. Altimari, A.; Fiorentino, M.; Gabusi, E.; Gruppioni, E.; Corti, B.; D’Errico, A.; Grigioni, W.F. Investigation of ErbB1 and ErbB2 expression for therapeutic targeting in primary liver tumours. Dig. Liver Dis. 2003, 35, 332-338. [CrossRef]

215. Nakazawa, K.; Dobashi, Y.; Suzuki, S.; Fujii, H.; Takeda, Y.; Ooi, A. Amplification and overexpression of c-ErbB-2, epidermal growth factor receptor, and c-Met in biliary tract cancers. J. Pathol. 2005, 206, 356-365. [CrossRef] [PubMed]

216. Nonomura, A.; Ohta, G.; Nakanuma, Y.; Izumi, R.; Mizukami, Y.; Matsubara, F.; Hayashi, M.; Watanabe, K.; Takayanagi, N. Simultaneous detection of epidermal growth factor receptor (EGF-R), epidermal growth factor (EGF) and ras p21 in cholangiocarcinoma by an immunocytochemical method. Liver 1988, 8, 157-166. [CrossRef] [PubMed]

217. Jan, Y.Y.; Yeh, T.S.; Yeh, J.N.; Yang, H.R.; Chen, M.F. Expression of epidermal growth factor receptor, apomucins, matrix metalloproteinases, and p53 in rat and human cholangiocarcinoma: Appraisal of an animal model of cholangiocarcinoma. Ann. Surg. 2004, 240, 89-94. [CrossRef] [PubMed]

218. Yoshikawa, D.; Ojima, H.; Iwasaki, M.; Hiraoka, N.; Kosuge, T.; Kasai, S.; Hirohashi, S.; Shibata, T. Clinicopathological and prognostic significance of EGFR, VEGF, and HER2 expression in cholangiocarcinoma. Br. J. Cancer 2008, 98, 418-425. [CrossRef] [PubMed]

219. Yang, X.; Wang, W.; Wang, C.; Wang, L.; Yang, M.; Qi, M.; Su, H.; Sun, X.; Liu, Z.; Zhang, J.; et al. Characterization of EGFR family gene aberrations in cholangiocarcinoma. Oncol. Rep. 2014, 32, 700-708. [CrossRef] [PubMed]

220. Harder, J.; Waiz, O.; Otto, F.; Geissler, M.; Olschewski, M.; Weinhold, B.; Blum, H.E.; Schmitt-Graeff, A.; Opitz, O.G. EGFR and HER2 expression in advanced biliary tract cancer. World J. Gastroenterol. 2009, 15, 4511-4517. [CrossRef] [PubMed]

221. Bekaii-Saab, T.; Williams, N.; Plass, C.; Calero, M.V.; Eng, C. A novel mutation in the tyrosine kinase domain of ErbB2 in hepatocellular carcinoma. BMC Cancer 2006, 6, 278. [CrossRef] [PubMed] 
222. Leone, F.; Cavalloni, G.; Pignochino, Y.; Sarotto, I.; Ferraris, R.; Piacibello, W.; Venesio, T.; Capussotti, L.; Risio, M.; Aglietta, M. Somatic mutations of epidermal growth factor receptor in bile duct and gallbladder carcinoma. Clin. Cancer Res. 2006, 12, 1680-1685. [CrossRef] [PubMed]

223. Gwak, G.Y.; Yoon, J.H.; Shin, C.M.; Ahn, Y.J.; Chung, J.K.; Kim, Y.A.; Kim, T.Y.; Lee, H.S. Detection of response-predicting mutations in the kinase domain of the epidermal growth factor receptor gene in cholangiocarcinomas. J. Cancer Res. Clin. Oncol. 2005, 131, 649-652. [CrossRef] [PubMed]

224. Kim, H.J.; Kim, J.S.; Kang, C.D.; Lee, S.J.; Kim, J.Y.; Yeon, J.E.; Park, J.J.; Shim, J.J.; Byun, K.S.; Bak, Y.T.; et al. Expression of epidermal growth factor receptor, ErbB2 and matrix metalloproteinase-9 in hepatolithiasis and cholangiocarcinoma. Korean J. Gastroenterol. 2005, 45, 52-59. [PubMed]

225. Zhou, Q.; Gong, Y.; Huang, F.; Lin, Q.; Zeng, B.; Li, Z.; Chen, R. Expression levels and significance of nuclear factor- $\mathrm{kB}$ and epidermal growth factor receptor in hepatolithiasis associated with intrahepatic cholangiocarcinoma. Dig. Surg. 2013, 30, 309-316. [CrossRef] [PubMed]

226. Sung, R.; Lee, S.H.; Ji, M.; Han, J.H.; Kang, M.H.; Kim, J.H.; Choi, J.W.; Kim, Y.C.; Park, S.M. Epithelial-mesenchymal transition-related protein expression in biliary epithelial cells associated with hepatolithiasis. J. Gastroenterol. Hepatol. 2014, 29, 395-402. [CrossRef] [PubMed]

227. Claperon, A.; Mergey, M.; Nguyen Ho-Bouldoires, T.H.; Vignjevic, D.; Wendum, D.; Chretien, Y.; Merabtene, F.; Frazao, A.; Paradis, V.; Housset, C.; et al. EGF/EGFR axis contributes to the progression of cholangiocarcinoma through the induction of an epithelial-mesenchymal transition. J. Hepatol. 2014, 61, 325-332. [CrossRef] [PubMed]

228. Claperon, A.; Guedj, N.; Mergey, M.; Vignjevic, D.; Desbois-Mouthon, C.; Boissan, M.; Saubamea, B.; Paradis, V.; Housset, C.; Fouassier, L. Loss of EBP50 stimulates EGFR activity to induce EMT phenotypic features in biliary cancer cells. Oncogene 2012, 31, 1376-1388. [CrossRef] [PubMed]

229. Carraway, K.L.; Ramsauer, V.P.; Haq, B.; Carothers Carraway, C.A. Cell signaling through membrane mucins. BioEssays 2003, 25, 66-71. [CrossRef] [PubMed]

230. Singh, P.K.; Hollingsworth, M.A. Cell surface-associated mucins in signal transduction. Trends Cell Biol. 2006, 16, 467-476. [CrossRef] [PubMed]

231. Pochampalli, M.R.; el Bejjani, R.M.; Schroeder, J.A. Muc1 is a novel regulator of ErbB1 receptor trafficking. Oncogene 2007, 26, 1693-1701. [CrossRef] [PubMed]

232. Lee, M.J.; Yu, G.R.; Yoo, H.J.; Kim, J.H.; Yoon, B.I.; Choi, Y.K.; Kim, D.G. Anxa8 down-regulation by EGF-FOXO4 signaling is involved in cell scattering and tumor metastasis of cholangiocarcinoma. Gastroenterology 2009, 137, 1138-1150, 1150 e1131-1139. [CrossRef] [PubMed]

233. Iwaki, J.; Kikuchi, K.; Mizuguchi, Y.; Kawahigashi, Y.; Yoshida, H.; Uchida, E.; Takizawa, T. miR-376c down-regulation accelerates EGF-dependent migration by targeting GRB2 in the HuCCT1 human intrahepatic cholangiocarcinoma cell line. PLoS ONE 2013, 8, e69496. [CrossRef] [PubMed]

234. Gui, A.; Kobayashi, A.; Motoyama, H.; Kitazawa, M.; Takeoka, M.; Miyagawa, S. Impaired degradation followed by enhanced recycling of epidermal growth factor receptor caused by hypo-phosphorylation of tyrosine 1045 in rbe cells. BMC Cancer 2012, 12, 179. [CrossRef] [PubMed]

235. Claperon, A.; Mergey, M.; Aoudjehane, L.; Ho-Bouldoires, T.H.; Wendum, D.; Prignon, A.; Merabtene, F.; Firrincieli, D.; Desbois-Mouthon, C.; Scatton, O.; et al. Hepatic myofibroblasts promote the progression of human cholangiocarcinoma through activation of epidermal growth factor receptor. Hepatology 2013, 58, 2001-2011. [CrossRef] [PubMed]

236. Xu, L.; Hausmann, M.; Dietmaier, W.; Kellermeier, S.; Pesch, T.; Stieber-Gunckel, M.; Lippert, E.; Klebl, F.; Rogler, G. Expression of growth factor receptors and targeting of EGFR in cholangiocarcinoma cell lines. BMC Cancer 2010, 10, 302. [CrossRef] [PubMed]

237. Zhang, F.; Li, L.; Yang, X.; Wang, B.; Zhao, J.; Lu, S.; Yu, X. Expression and activation of EGFR and STAT3 during the multistage carcinogenesis of intrahepatic cholangiocarcinoma induced by $3^{\prime}$-methyl-4 dimethylaminoazobenzene in rats. J. Toxicol. Pathol. 2015, 28, 79-87. [CrossRef] [PubMed]

238. Sirica, A.E. Role of ErbB family receptor tyrosine kinases in intrahepatic cholangiocarcinoma. World J. Gastroenterol. 2008, 14, 7033-7058. [CrossRef] [PubMed]

239. Andersen, J.B.; Spee, B.; Blechacz, B.R.; Avital, I.; Komuta, M.; Barbour, A.; Conner, E.A.; Gillen, M.C.; Roskams, T.; Roberts, L.R.; et al. Genomic and genetic characterization of cholangiocarcinoma identifies therapeutic targets for tyrosine kinase inhibitors. Gastroenterology 2012, 142, 1021-1031 e1015. [CrossRef] [PubMed] 
240. Philip, P.A.; Mahoney, M.R.; Allmer, C.; Thomas, J.; Pitot, H.C.; Kim, G.; Donehower, R.C.; Fitch, T.; Picus, J.; Erlichman, C. Phase ii study of erlotinib in patients with advanced biliary cancer. J. Clin. Oncol. 2006, 24, 3069-3074. [CrossRef] [PubMed]

241. Huang, T.W.; Wang, C.H.; Hsieh, C.B. Effects of the anti-epidermal growth factor receptor antibody cetuximab on cholangiocarcinoma of the liver. Onkologie 2007, 30, 129-131. [CrossRef] [PubMed]

242. Sprinzl, M.F.; Schimanski, C.C.; Moehler, M.; Schadmand-Fischer, S.; Galle, P.R.; Kanzler, S. Gemcitabine in combination with EGF-receptor antibody (Cetuximab) as a treatment of cholangiocarcinoma: A case report. BMC Cancer 2006, 6. [CrossRef] [PubMed]

243. Paule, B.; Herelle, M.O.; Rage, E.; Ducreux, M.; ADAM, R.; Guettier, C.; Bralet, M.P. Cetuximab plus gemcitabine-oxaliplatin (GEMOX) in patients with refractory advanced intrahepatic cholangiocarcinomas. Oncology 2007, 72, 105-110. [CrossRef] [PubMed]

244. Siegel-Lakhai, W.S.; Beijnen, J.H.; Vervenne, W.L.; Boot, H.; Keessen, M.; Versola, M.; Koch, K.M.; Smith, D.A.; Pandite, L.; Richel, D.J.; et al. Phase I pharmacokinetic study of the safety and tolerability of lapatinib (GW572016) in combination with oxaliplatin/fluorouracil/leucovorin (FOLFOX4) in patients with solid tumors. Clin. Cancer Res. 2007, 13, 4495-4502. [CrossRef] [PubMed]

245. Changbumrung, S.; Tungtrongchitr, R.; Migasena, P.; Chamroenngan, S. Serum unconjugated primary and secondary bile acids in patients with cholangiocarcinoma and hepatocellular carcinoma. J. Med. Assoc. Thail. 1990, 73, 81-90.

246. Kinami, Y.; Ashida, Y.; Gotoda, H.; Seto, K.; Kojima, Y.; Takashima, S. Promoting effects of bile acid load on the occurrence of cholangiocarcinoma induced by diisopropanolnitrosamine in hamsters. Oncology 1993, 50, 46-51. [CrossRef] [PubMed]

247. Kinami, Y.; Miyakoshi, M.; Fujikawa, K. Bile acid load on the DNA distribution pattern of bile ductules and cholangiocarcinoma induced by diisopropanolnitrosamine in hamsters. Oncology 1998, 55, 77-86. [CrossRef] [PubMed]

248. Liu, R.; Zhao, R.; Zhou, X.; Liang, X.; Campbell, D.J.; Zhang, X.; Zhang, L.; Shi, R.; Wang, G.; Pandak, W.M.; et al. Conjugated bile acids promote cholangiocarcinoma cell invasive growth through activation of sphingosine 1-phosphate receptor 2. Hepatology 2014, 60, 908-918. [CrossRef] [PubMed]

249. Jones, H.; Alpini, G.; Francis, H. Bile acid signaling and biliary functions. Acta Pharm. Sin. B 2015, 5, 123-128. [CrossRef] [PubMed]

250. Yoon, J.H.; Higuchi, H.; Werneburg, N.W.; Kaufmann, S.H.; Gores, G.J. Bile acids induce cyclooxygenase-2 expression via the epidermal growth factor receptor in a human cholangiocarcinoma cell line. Gastroenterology 2002, 122, 985-993. [CrossRef] [PubMed]

251. Yoon, J.H.; Werneburg, N.W.; Higuchi, H.; Canbay, A.E.; Kaufmann, S.H.; Akgul, C.; Edwards, S.W.; Gores, G.J. Bile acids inhibit Mcl-1 protein turnover via an epidermal growth factor receptor/Raf-1-dependent mechanism. Cancer Res. 2002, 62, 6500-6505. [PubMed]

252. Kim, K.M.; Yoon, J.H.; Gwak, G.Y.; Kim, W.; Lee, S.H.; Jang, J.J.; Lee, H.S. Bile acid-mediated induction of cyclooxygenase-2 and Mcl-1 in hepatic stellate cells. Biochem. Biophys. Res. Commun. 2006, 342, 1108-1113. [CrossRef] [PubMed]

253. Zhang, L.; Jiang, L.; Sun, Q.; Peng, T.; Lou, K.; Liu, N.; Leng, J. Prostaglandin e2 enhances mitogen-activated protein kinase/ERK pathway in human cholangiocarcinoma cells: Involvement of ep1 receptor, calcium and EGF receptors signaling. Mol. Cell. Biochem. 2007, 305, 19-26. [CrossRef] [PubMed]

254. Yoon, J.H.; Gwak, G.Y.; Lee, H.S.; Bronk, S.F.; Werneburg, N.W.; Gores, G.J. Enhanced epidermal growth factor receptor activation in human cholangiocarcinoma cells. J. Hepatol. 2004, 41, 808-814. [CrossRef] [PubMed]

255. Bird, T.G.; Lorenzini, S.; Forbes, S.J. Activation of stem cells in hepatic diseases. Cell Tissue Res. 2008, 331, 283-300. [CrossRef] [PubMed]

256. Russo, F.P.; Parola, M. Stem and progenitor cells in liver regeneration and repair. Cytotherapy 2011, 13, 135-144. [CrossRef] [PubMed]

257. Roskams, T.; Katoonizadeh, A.; Komuta, M. Hepatic progenitor cells: An update. Clin. Liver Dis. 2010, 14, 705-718. [CrossRef] [PubMed]

258. Rountree, C.B.; Mishra, L.; Willenbring, H. Stem cells in liver diseases and cancer: Recent advances on the path to new therapies. Hepatology 2012, 55, 298-306. [CrossRef] [PubMed] 
259. Nagy, P.; Bisgaard, H.C.; Santoni-Rugiu, E.; Thorgeirsson, S.S. In vivo infusion of growth factors enhances the mitogenic response of rat hepatic ductal (oval) cells after administration of 2-acetylaminofluorene. Hepatology 1996, 23, 71-79. [CrossRef] [PubMed]

260. Kitade, M.; Factor, V.M.; Andersen, J.B.; Tomokuni, A.; Kaji, K.; Akita, H.; Holczbauer, A.; Seo, D.; Marquardt, J.U.; Conner, E.A.; et al. Specific fate decisions in adult hepatic progenitor cells driven by Met and EGFR signaling. Genes Dev. 2013, 27, 1706-1717. [CrossRef] [PubMed]

261. Jin, C.; Samuelson, L.; Cui, C.B.; Sun, Y.; Gerber, D.A. MAPK/ERK and Wnt/ $\beta$-catenin pathways are synergistically involved in proliferation of Sca-1 positive hepatic progenitor cells. Biochem. Biophys. Res. Commun. 2011, 409, 803-807. [CrossRef] [PubMed]

262. Huitfeldt, H.S.; Skarpen, E.; Lindeman, B.; Becher, R.; Thrane, E.V.; Schwarze, P.E. Differential distribution of Met and epidermal growth factor receptor in normal and carcinogen-treated rat liver. J. Histochem. Cytochem. Soc. 1996, 44, 227-233. [CrossRef]

263. Hu, Z.; Evarts, R.P.; Fujio, K.; Omori, N.; Omori, M.; Marsden, E.R.; Thorgeirsson, S.S. Expression of transforming growth factor $\alpha$ /epidermal growth factor receptor, hepatocyte growth factor/c-Met and acidic fibroblast growth factor/fibroblast growth factor receptors during hepatocarcinogenesis. Carcinogenesis 1996, 17, 931-938. [CrossRef] [PubMed]

264. Evarts, R.P.; Nakatsukasa, H.; Marsden, E.R.; Hu, Z.; Thorgeirsson, S.S. Expression of transforming growth factor- $\alpha$ in regenerating liver and during hepatic differentiation. Mol. Carcinogenes. 1992, 5, 25-31. [CrossRef]

265. Evarts, R.P.; Hu, Z.; Fujio, K.; Marsden, E.R.; Thorgeirsson, S.S. Activation of hepatic stem cell compartment in the rat: Role of transforming growth factor $\alpha$, hepatocyte growth factor, and acidic fibroblast growth factor in early proliferation. Cell Growth Differ. 1993, 4, 555-561. [PubMed]

266. Isfort, R.J.; Cody, D.B.; Stuard, S.B.; Randall, C.J.; Miller, C.; Ridder, G.M.; Doersen, C.J.; Richards, W.G.; Yoder, B.K.; Wilkinson, J.E.; et al. The combination of epidermal growth factor and transforming growth factor- $\beta$ induces novel phenotypic changes in mouse liver stem cell lines. J. Cell Sci. 1997, $110 \mathrm{Pt} \mathrm{24,}$ 3117-3129. [PubMed]

267. Friedman, S.L. Mechanisms of hepatic fibrogenesis. Gastroenterology 2008, 134, 1655-1669. [CrossRef] [PubMed]

268. Wang, P.; Liu, T.; Cong, M.; Wu, X.; Bai, Y.; Yin, C.; An, W.; Wang, B.; Jia, J.; You, H. Expression of extracellular matrix genes in cultured hepatic oval cells: An origin of hepatic stellate cells through transforming growth factor $\beta$ ? Liver Int. 2009, 29, 575-584. [CrossRef] [PubMed]

269. Wu, K.; Ding, J.; Chen, C.; Sun, W.; Ning, B.F.; Wen, W.; Huang, L.; Han, T.; Yang, W.; Wang, C.; et al. Hepatic transforming growth factor $\beta$ gives rise to tumor-initiating cells and promotes liver cancer development. Hepatology 2012, 56, 2255-2267. [CrossRef] [PubMed]

270. Fabregat, I.; Sanchez, A.; Alvarez, A.M.; Nakamura, T.; Benito, M. Epidermal growth factor, but not hepatocyte growth factor, suppresses the apoptosis induced by transforming growth factor- $\beta$ in fetal hepatocytes in primary culture. FEBS Lett. 1996, 384, 14-18. [CrossRef]

271. Martinez-Palacian, A.; del Castillo, G.; Herrera, B.; Fernandez, M.; Roncero, C.; Fabregat, I.; Sanchez, A. EGFR is dispensable for c-Met-mediated proliferation and survival activities in mouse adult liver oval cells. Cell. Signal. 2012, 24, 505-513. [CrossRef] [PubMed]

272. Wang, P.; Yang, A.T.; Cong, M.; Liu, T.H.; Zhang, D.; Huang, J.; Tong, X.F.; Zhu, S.T.; Xu, Y.; Tang, S.Z.; et al. EGF suppresses the initiation and drives the reversion of TGF- $\beta 1$-induced transition in hepatic oval cells showing the plasticity of progenitor cells. J. Cell. Physiol. 2015, 230, 2362-2370. [CrossRef] [PubMed]

273. Santoro, A.; Rimassa, L.; Borbath, I.; Daniele, B.; Salvagni, S.; Van Laethem, J.L.; Van Vlierberghe, H.; Trojan, J.; Kolligs, F.T.; Weiss, A.; et al. Tivantinib for second-line treatment of advanced hepatocellular carcinoma: A randomised, placebo-controlled phase 2 study. Lancet Oncol. 2013, 14, 55-63. [CrossRef]

(C) 2015 by the authors; licensee MDPI, Basel, Switzerland. This article is an open access article distributed under the terms and conditions of the Creative Commons by Attribution (CC-BY) license (http:/ / creativecommons.org/licenses/by/4.0/). 